\title{
Bone Metastases from Gastric Cancer: What We Know and How to Deal with Them
}

\author{
Angelica Petrillo 1,2,*化, Emilio Francesco Giunta 1,2 ${ }^{\mathbb{D}}$, Annalisa Pappalardo ${ }^{1,2}$, Davide Bosso ${ }^{1}$, Laura Attademo ${ }^{1}$, \\ Cinzia Cardalesi ${ }^{1}$, Anna Diana 1,2 ${ }^{1}$, Antonietta Fabbrocini ${ }^{1}$, Teresa Fabozzi ${ }^{1}$, Pasqualina Giordano ${ }^{1}$, \\ Margaret Ottaviano ${ }^{1,3,4} \mathbb{(}$, Mario Rosanova ${ }^{1}$, Antonia Silvestri ${ }^{1}$, Piera Federico ${ }^{1}{ }^{1}$ and Bruno Daniele ${ }^{1}(\mathbb{D}$
}

\section{check for}

updates

Citation: Petrillo, A.; Giunta, E.F.; Pappalardo, A.; Bosso, D.; Attademo,

L.; Cardalesi, C.; Diana, A.;

Fabbrocini, A.; Fabozzi, T.; Giordano,

P.; et al. Bone Metastases from Gastric Cancer: What We Know and How to Deal with Them. J. Clin. Med. 2021, 10, 1777. https://doi.org/10.3390/ jcm10081777

Academic Editors: Mohammad H. Derakhshan and Hidekazu Suzuki

Received: 8 January 2021

Accepted: 12 April 2021

Published: 19 April 2021

Publisher's Note: MDPI stays neutral with regard to jurisdictional claims in published maps and institutional affiliations.

Copyright: (c) 2021 by the authors. Licensee MDPI, Basel, Switzerland. This article is an open access article distributed under the terms and conditions of the Creative Commons Attribution (CC BY) license (https:/ / creativecommons.org/licenses/by/ $4.0 /)$.
1 Medical Oncology Unit, Ospedale del Mare, 80147 Naples, Italy; emiliofrancescogiunta@gmail.com (E.F.G.); annalisa.pappalardo88@gmail.com (A.P.); davidebosso84@gmail.com (D.B.); laura.attademo@gmail.com (L.A.); cinzia.cardalesi@gmail.com (C.C.); annadiana88@gmail.com (A.D.); antonietta.fabbrocini@gmail.com (A.F.); fabozzit79@gmail.com (T.F.); giopas@email.it (P.G.); margaretottaviano@gmail.com (M.O.); rosanovamario@hotmail.com (M.R.); antonia.silv@libero.it (A.S.); pierafederico@yahoo.it (P.F.); b.daniele@libero.it (B.D.)

2 Department of Precision Medicine, School of Medicine, University of Study of Campania "L. Vanvitelli", 80131 Naples, Italy

3 Department of Clinical Medicine and Surgery, University of Naples "Federico II", 80131 Naples, Italy

4 CRCTR Rare Tumors Reference Center of Campania Region, 80131 Naples, Italy

* Correspondence: angelic.petrillo@gmail.com

\begin{abstract}
Gastric cancer (GC) is the third cause of cancer-related death worldwide; the prognosis is poor especially in the case of metastatic disease. Liver, lymph nodes, peritoneum, and lung are the most frequent sites of metastases from GC; however, bone metastases from GC have been reported in the literature. Nevertheless, it is unclear how the metastatic sites may affect the prognosis. In particular, knowledge about the impact of bone metastases on GC patients' outcome is scant, and this may be related to the rarity of bone lesions and/or their underestimation at the time of diagnosis. In fact, there is still a lack of specific recommendation for their detection at the diagnosis. Then, the majority of the evidences in this field came from retrospective analysis on very heterogeneous study populations. In this context, the aim of this narrative review is to delineate an overview about the evidences existing about bone metastases in GC patients, focusing on their incidence and biology, the prognostic role of bone involvement, and their possible implication in the treatment choice.
\end{abstract}

Keywords: metastatic gastric cancer; target therapy; bone flare; stage IV; treatment; RANK-L

\section{Introduction}

Gastric cancer (GC) is the third cause of cancer-related death worldwide [1]. In particular, even today, survival is dismal, and only $5.5 \%$ of patients diagnosed with metastatic GC are alive at 5 years [2]. Although over the last decades the research in GC has focused on the role of novel and targeted treatments, chemotherapy based on a doublet with platin and fluorouracil remains the standard of care for the first-line therapy in case of metastatic disease without overexpression of human epithelial growth factor 2 receptor (HER2) [3]. To date, trastuzumab is the unique target agent approved for first-line treatment of HER2positive metastatic GC in addition to the doublet chemotherapy backbone, due to the fact that all the other targeted agents failed to improve survival outcomes in this setting [4,5]. Recently, the immune checkpoint inhibitors have shown promising results in the treatment of first-line metastatic GC [6-8]. However, data are preliminary, and the final results of the trials are awaited in order to clarify their role in the first-line treatment of metastatic GC. Therefore, these agents have not been approved by the regulatory authorities yet, and their use is not a standard of care at the time of writing.

In the last decades, one of the most important conceptual achievements in this field is represented by the "continuum of care", meaning the possibility to treat patients with 
multiple subsequent lines of therapy in order to obtain longer survivals. In fact, almost $40 \%$ of patients receiving a first-line treatment for metastatic disease maintains a good performance status after progression; they are able to receive a second and even a third line of treatment $[9,10]$. In the second line, a treatment with paclitaxel and ramucirumab is the standard of care in case of patients with good performance status (PS 0-1 according to the Eastern Cooperative Oncology Group (ECOG) scale); otherwise, ramucirumab as monotherapy is the preferred choice in case of patients with ECOG PS 2 [3]. Then, up to date, triflurifine/tipiracil is the unique agent to have shown a benefit as third line treatment in patients with metastatic GC and good PS, representing the standard choice in this field after the approval of local authorities [3]. Thus, moving from the experience in colorectal cancer patients [11], the definition of the right sequence of treatment from the diagnosis is becoming crucial in GC as well [12].

Over the last decades, a better understanding of molecular patterns of metastatic GC led to validated molecular classifications [13,14], indicating that GC is no longer a single entity, while it includes many subgroups with their own peculiarities and different behavior. However, so far, these molecular classifications have not been applied diffusely in the everyday clinical practice. Additionally, there is still a lack of validated prognostic and predictive biomarkers in GC able to guide the choice of a tailored treatment for each patient [15]. Therefore, the treatment algorithm for metastatic GC is often painted according to the patient's (age, PS, comorbidities, and nutritional assessment) or tumor's (tumor burden, symptomatic disease, metastatic sites) characteristics. Thus, a multidisciplinary evaluation of each patient is crucial in the treatment decision process.

In this context, it is unclear how the sites of metastases may affect the prognosis. In fact, if the presence of peritoneal disease or of multiple metastatic sites is considered a well-known worse prognostic factor [16], the knowledge about the role of bone metastases or other visceral sites, such as lung, is scant. This could be related to the rarity of bone involvement in GC, representing the fifth metastatic site after liver, peritoneum, lymph nodes, and-according to the series-lung. Additionally, they are often underestimated at the diagnosis due to the lack of specific recommendation for their detection. Thus, bone metastases have been typically searched for only in case of appearance of new symptoms (e.g., pain), and a consistent fraction of them have been recognized only post-mortem during autopsy in case of non-symptomatic disease [17].

Based on this background, the aim of this narrative review is to describe the evidence existing about bone metastases in GC patients, focusing on their incidence and biology, their prognostic role, and possible implication in the treatment choice.

\section{The Biological Basis of Bone Involvement in Metastatic Gastric Cancer}

From a biological point of view, bones are a unique and favored site for metastases from several types of cancer, and complex mechanisms are responsible for the development of bone metastasis [18,19]. The cells mostly responsible for bone metabolism are osteoblasts, osteoclasts and osteocytes. In general, osteoblasts produce a bone matrix, called osteoid, which consists of proteins, mainly type I collagen ( $95 \%$ ), and they synthesize hydroxyapatite crystals, mineralizing the bone matrix; at the end of their synthetic processes, some osteoblasts are "trapped" into their own matrix and become osteocytes [20]. Osteoblasts, which derived from mesenchymal stem cells, are primarily responsible for bone formation; however, they are also involved in bone destruction [21]. In fact, these cells could be stimulated in both physiological and pathological conditions through the excretion of parathormone (PTH) or, in pathological conditions only, through its related peptidePTHrP- to overproduce the Receptor Activator of Nuclear factor- $\kappa B$ Ligand (RANK-L) [22]. RANK-L-a member of the RANKL/RANK/osteoprotegerin (OPG) pathway and belonging to tumor necrosis factor (TNF) superfamily - exists both as a transmembrane protein and as a soluble form; it interacts with RANK on the surface of osteoclasts, resulting in their activation via transcription factors [23,24]. Preclinical studies have shown that RANK-L is able to promote the migration of breast cancer cells [25] but also of GC cells. Interestingly, 
in GC it could interact with epidermal growth factor receptor (EGFR) [26]. Osteoblasts are also able to reduce osteoclastogenic activity by expressing OPG, which is a decoy receptor for RANKL that prevents RANK signaling activation [27].

Osteoclasts are multinucleated cells deriving from the monocyte/macrophage lineage, which is responsible for bone resorption by creating sealed zones. In these zones, they can dissolve bone minerals and degrade extracellular matrix (ECM) bone proteins through the secretion of $\mathrm{H}+, \mathrm{Cl}$ - and enzymes such as cathepsin $\mathrm{K}$ and matrix metalloproteinases (MMPs) [28]. During this process, growth factors-namely bone morphogenetic proteins (BMPs) and fibroblast growth factors-are released from the bone matrix; this release causes the attraction of osteoblasts and the start of a new cycle inside the Bone Remodeling Compartment $[29,30]$. In adulthood, in physiological conditions, bone remodeling reaches equilibrium between formation and resorption. Nevertheless, the quantity of bone loss is not entirely replaced over the years, causing an unrelenting decline in bone mass with aging [31,32].

Several steps are required for bone metastases development: first of all, cells from the primary tumor should reach bones through systemic circulation; then, they enter the bone microenvironment, especially in areas of the skeleton characterized by high vascularization, such as bones with red marrow [33]. The hypothesis of vascular niches in the bone microenvironment, which promotes the skeletal localization of tumor cells through their extravasation and docking, is supported by the discovery of biological and molecular mechanisms, such as cytokines, adhesion molecules, and skeletal endothelial cells properties [34]. Additionally, the dormancy of disseminated tumor cells, followed by their reactivation and proliferation, is a poorly understood process involved in bone metastases development [35].

Although during metastatic dissemination, the circulating tumor cells could localize in bone marrow virtually in all types of solid tumors [36], differences in the incidence of bone metastases across distinct primary tumor sites have suggested the implication of specific and histotype-related mechanisms. In fact, there are several mechanisms-that are not entirely understood - that could lead to a distinct pattern of metastatization, also according to the heterogeneity of primary tumor. In this context, an analysis on 910 samples from 100 patients affected by renal cancer showed that monoclonal tumors tend to provide a more rapid metastatization to multiple sites. Otherwise, heterogeneous tumors had late progression as single metastatic lesions [19]. Nevertheless, bone metastases from gastrointestinal cancers are quite uncommon [33].

Regarding GC, it is still not very clear how the tumor cells colonize the bone microenvironment. Since bone metastases are the results of hematogenous spreading of cancer cells, preferential ways among venous systems, potentially used by GC cells to reach the skeleton, have not been identified [37]. Angiogenesis, which is involved in gastric carcinogenesis and tumor progression, could play a primary role in bone metastasis growth [38]. Among the actors of tumoral angiogenesis, mast cells positive to tryptase (MCPT) have demonstrated to be positively associated with neovascularization in bone metastases from GC, identifying them as a new potential anti-tumor target [39].

PTHrP has been found to be expressed in several epithelial cancers, including gastric adenocarcinoma [40], where it was found to be overexpressed in moderately and poorly differentiated tumors as well as in metastatic sites [41,42]. However, no association with an increased risk of bone metastases has been reported in gastric adenocarcinomas overproducing PTHrP [42].

RANKL expression in resected GC has been associated to high risk of distant metastases and poor prognosis [43]. However, to date no correlation between RANKL expression and bone metastases development risk has been found in those tumors.

Finally, BMP4 has been described to be overexpressed in GC [44]. In an in vivo model of prostate cancer, BMP4 favors tumor growth in bone by tumor-induced osteogenesis [45]. In GC cells, BMP4 could be responsible for the development of metastasis by enhancing 
epithelial-mesenchymal transition (EMT) [46]. However, despite of these evidences, the role of BMP4 role in bone metastases from GC should be further elucidated.

\section{Clinical Overview on Bone Metastases from Gastric Cancer}

The skeleton has been considered a typical metastatic site in some kind of tumors, such as breast or prostate cancer $[47,48]$. However, bone involvement is considered unusual in GC. In fact, the little evidence that exists in the literature has shown that bone metastases occur in metastatic GC patients in a range between $0.9 \%$ and $13.4 \%$, according to the study population [17,49-62]. However, it is important to note that these data mostly come from retrospective analysis and case series. Therefore, no prospective evaluation regarding the characteristics and distribution of bone metastasis in GC exists to date.

In general, the most important issues to consider in the knowledge of bone metastases in GC patients are the time of onset (at diagnosis-synchronous, or at the time of progression-metachronous), the type of metastases (osteolytic, osteoblastic, or mixed), their distribution (axial versus appendicular skeleton), the prognostic implications of metastatic bone involvement and correlation with other patients' and tumor's clinicopathological characteristics.

\subsection{Incidence, Onset, Type and Distribution}

Moving from the first historical report by Yoshikawa et al. in 1983 [17], showing 33 GC patients with bone metastases, the research has focused on this topic especially over the last decade. Table 1 summarizes the most significant data reported in the literature regarding the descriptive evaluation of bone metastases in GC, including time of onset, type, and distribution. Of note, the articles that were not available in English were not considered in this review.

Among the available studies, a retrospective Italian analysis, which collected the data from 2000 metastatic GC patients treated at 22 centers over 12 years (from 1998 to 2011), is one of the largest multicenter experiences in this context [55]. The trial showed a bone involvement in $10 \%$ of metastatic GC patients (208 patients); of them, $28 \%$ were diagnosed with bone metastasis (synchronous disease), whereas $62 \%$ had a bone progression of disease (metachronous disease). The majority of patients were young ( $<61$ years old: $52.9 \%)$, male (66\%), showing an ECOG PS 1 (43.9\%); the most frequent disease characteristics were the following: intestinal subtype according to Lauren classification (38.9\%) [63], grade $3(81.3 \%), \mathrm{N} 2$ involvement according to TNM stage $(41.5 \%)$, and concurrent visceral metastasis $(86.3 \%)$. It is important to underline that $27 \%$ of patients had an ECOG PS $2-3$ at the diagnosis of bone involvement; additionally, 33\% of patients had a diffuse tumor subtype according to Lauren classification [63]. Regarding the type and distribution of the lesions, the majority of patients included in the study population had multiple bone metastasis, especially in the long bones (52\%); those lesions were mostly osteolytic (52\% versus $25 \%$ mixed lesions and $23 \%$ osteoblastic ones). 
Table 1. Clinical overview about bone metastases characteristics in gastric cancer patients.

\begin{tabular}{|c|c|c|c|c|c|c|c|c|c|}
\hline $\begin{array}{l}\text { Author } \\
\text { and year * }\end{array}$ & $\begin{array}{l}\text { Study Design, } \\
\text { Timeline, } \\
\text { Country }\end{array}$ & $\begin{array}{l}\text { N Patients } \\
\text { Analyzed }\end{array}$ & $\begin{array}{c}\text { N Patient with } \\
\text { Bone } \\
\text { Metastasis (\%) }\end{array}$ & Onset & Type & Distribution & $\begin{array}{l}\text { Main Patients' } \\
\text { Characteristics }\end{array}$ & $\begin{array}{l}\text { Main Tumor's } \\
\text { Characteristics }\end{array}$ & Outcomes \\
\hline $\begin{array}{l}\text { Yoshikawa } \\
\text { et al., } 1983 \\
\text { [17] }\end{array}$ & $\begin{array}{l}\text { Retrospective } \\
\text { Monoinstitutional } \\
\text { 1970-1979 } \\
\text { Japan }\end{array}$ & 1945 & $23(1.2 \%)$ & NR & NR & $\begin{array}{c}\text { Thoracic } \\
\text { vertebrae: } 69.6 \% \text {; } \\
\text { Lumbar vertebrae: } \\
69.6 \% ; \\
\text { Pelvic bones: } \\
26.1 \% ; \\
\text { Ribs: } 21.7 \%\end{array}$ & $\begin{array}{c}\text { Young (age <60: } \\
78.3 \%) ; \\
\text { male: } 56.5 \%\end{array}$ & NR & NR \\
\hline $\begin{array}{l}\text { Park et al., } \\
\text { 2011 } \\
\text { [59] }\end{array}$ & $\begin{array}{c}\text { Retrospective } \\
\text { Monoinstitutional } \\
\text { 1998-2008 } \\
\text { Korea }\end{array}$ & 8633 & $203(2.4 \%)$ & $\begin{array}{c}\text { Synchronous: } \\
62 \% ; \\
\text { Metachronous: } \\
38 \%\end{array}$ & NR & NR & $\begin{array}{c}\text { Median age: } \\
51 \text { years; } \\
\text { multiple metastatic } \\
\text { sites (bone and } \\
\text { visceral): } 84.7 \% \text {; } \\
\text { multiple bone } \\
\text { metastasis: } 88.7 \% \text {; } \\
\text { ECOG PS } 0-2: 82 \%\end{array}$ & $\begin{array}{c}\text { Poorly } \\
\text { differentiated: } \\
72 \%\end{array}$ & $\begin{array}{c}\text { mOS: } \\
3.4 \text { months }\end{array}$ \\
\hline $\begin{array}{l}\text { Park et al., } \\
2013 \text { [64] }\end{array}$ & $\begin{array}{c}\text { Retrospective } \\
\text { Monoinstitutional } \\
\text { 1989-2008 } \\
\text { Korea }\end{array}$ & 1683 & $30(1.8 \%)$ & $\begin{array}{l}\text { Metachronous: } \\
100 \%\end{array}$ & NR & $\begin{array}{c}\text { Vertebrae: } 93.3 \% \\
\text { pelvic: bones: } \\
40 \% \\
\text { ribs: } 33.3 \%\end{array}$ & $\begin{array}{c}\text { young (median age } \\
53.1 \text { years old) } \\
\text { male: } 63.3 \%\end{array}$ & $\begin{array}{c}\text { Undifferentiated: } \\
73 \% \\
\text { N3: } 43.3 \%\end{array}$ & $\begin{array}{l}\text { mOS after bone } \\
\text { recurrence: } \\
6 \text { months }\end{array}$ \\
\hline $\begin{array}{l}\text { Nakamura } \\
\text { et al., 2014 } \\
\text { [60] }\end{array}$ & $\begin{array}{l}\text { Retrospective } \\
\text { Monoinstitutional } \\
\text { 2000-2010 }\end{array}$ & 1837 & $31(1.7 \%)$ & $\begin{array}{c}\text { Synchronous: } \\
25.8 \% \text {; } \\
\text { Metachronous: } \\
74.2 \%\end{array}$ & NR & NR & $\begin{array}{c}\text { Age }<65: 51.6 \% \\
\text { multiple metastatic } \\
\text { sites (bone and } \\
\text { visceral): } 79.5 \% \text {; } \\
\text { multiple bone } \\
\text { metastasis: } 79.5 \% \text {; } \\
\text { ECOG PS 0-1: } \\
58.1 \%\end{array}$ & $\begin{array}{c}\text { Undifferentiated: } \\
67.8 \%\end{array}$ & $\begin{array}{c}\text { mOS: } \\
3.3 \text { months }\end{array}$ \\
\hline
\end{tabular}


Table 1. Cont.

\begin{tabular}{|c|c|c|c|c|c|c|c|c|c|}
\hline $\begin{array}{l}\text { Author } \\
\text { and year* }\end{array}$ & $\begin{array}{l}\text { Study Design, } \\
\text { Timeline, } \\
\text { Country } \\
\end{array}$ & $\begin{array}{l}\text { N Patients } \\
\text { Analyzed }\end{array}$ & $\begin{array}{c}\text { N Patient with } \\
\text { Bone } \\
\text { Metastasis (\%) }\end{array}$ & Onset & Type & Distribution & $\begin{array}{l}\text { Main Patients' } \\
\text { Characteristics }\end{array}$ & $\begin{array}{l}\text { Main Tumor's } \\
\text { Characteristics }\end{array}$ & Outcomes \\
\hline $\begin{array}{c}\text { Mikami et al., } \\
2017 \\
{[61]}\end{array}$ & $\begin{array}{l}\text { Retrospective } \\
\text { Monoinstitutional } \\
\text { 2010-2015 }\end{array}$ & NR & $34(100 \%)$ & $\begin{array}{c}\text { Synchronous: } \\
29.4 \% \text {; } \\
\text { Metachronous: } \\
70.6 \%\end{array}$ & NR & $\begin{array}{c}\text { Thoracic } \\
\text { vertebrae: } 55.9 \% \text {; } \\
\text { Pelvic bones: } \\
41.2 \% \text {; } \\
\text { Lumbar vertebrae: } \\
38.2 \% ; \\
\text { Ribs: } 29.4 \%\end{array}$ & $\begin{array}{c}\text { multiple metastatic } \\
\text { sites (bone and } \\
\text { visceral): } 76.5 \% \text {; } \\
\text { multiple bone } \\
\text { metastasis: } 64.7 \%\end{array}$ & $\begin{array}{l}\text { Undifferentiated: } \\
55.9 \%\end{array}$ & $\begin{array}{l}\text { mOS: } \\
7.5 \text { months }\end{array}$ \\
\hline $\begin{array}{l}\text { Qiu et al., } 2018 \\
\text { [58] }\end{array}$ & $\begin{array}{l}\text { Retrospective } \\
\text { Multicenter } \\
\text { 2010-2014 }\end{array}$ & 19022 & $966(5.1 \%)$ & NR & NR & NR & NR & $\begin{array}{c}\text { Intestinal: } 62 \% \\
\text { G3: } 60.7 \% \\
\text { located to the } \\
\text { cardia: } 38 \%\end{array}$ & $\begin{array}{c}\text { mOS: } 4 \text { months; } \\
5 \text { year CSS: } \\
1.27 \%\end{array}$ \\
\hline $\begin{array}{c}\text { Wen L et al., } \\
2019 \\
{[56]}\end{array}$ & $\begin{array}{l}\text { Retrospective } \\
\text { Monoinstitutional } \\
\text { 2008-2018 } \\
\text { China }\end{array}$ & 884 & $66(11.3 \%)$ & $\begin{array}{c}\text { Synchronous: } \\
45.5 \% \text {; } \\
\text { Metachronous: } \\
54.5 \%\end{array}$ & NR & $\begin{array}{c}\text { Spine: } 78.5 \% ; \\
\text { pelvic bones: } \\
68.2 \% \text {; } \\
\text { ribs: } 47.0 \% \text {; lower } \\
\text { extremity: } 34.8 \% ; \\
\text { sternum:33.3\%; } \\
\text { scapula: } 31.8 \% ; \\
\text { upper extremity: } \\
21.2 \% \\
\text { skull: } 19.7 \%\end{array}$ & $\begin{array}{c}\text { young (median age } \\
53 \text { years old) male: } \\
68.2 \% ; \\
\text { ECOG PS 0-1: } \\
68.2 \% ; \\
\text { multiple metastatic } \\
\text { sites (bone and } \\
\text { visceral): } 84.9 \% ; \\
\text { multiple bone } \\
\text { metastasis: } 84.8 \%\end{array}$ & $\begin{array}{c}\text { G3/mucinous/ } \\
\text { signet ring cells: } \\
71.2 \% ; \\
\text { located to the } \\
\text { antrum: } 30.3 \%\end{array}$ & $\begin{array}{c}\text { mOS: } \\
6.5 \text { months; } \\
\text { mOS } \\
\text { metachronous: } \\
\text { 11.8 months } \\
\text { synchronous: } \\
4.1 \text { months }\end{array}$ \\
\hline $\begin{array}{c}\text { Liang C et al., } \\
2020 \\
{[57]}\end{array}$ & $\begin{array}{l}\text { Retrospective } \\
\text { Multicenter } \\
\text { 2010-2016 }\end{array}$ & 42966 & $1798(4.2 \%)$ & NR & NR & NR & $\begin{array}{l}\text { multiple metastatic } \\
\text { sites (bone and } \\
\text { visceral): } 52.6 \%\end{array}$ & $\begin{array}{c}\text { Intestinal: } \\
\text { 60.8\%; } \\
\text { G3: } 62.2 \% \text {; } \\
\text { located to the } \\
\text { cardia: } 38.4 \% \\
\end{array}$ & mOS: 3 months \\
\hline $\begin{array}{c}\text { Imura et al., } \\
2020 \\
{[62]}\end{array}$ & $\begin{array}{l}\text { Retrospective } \\
\text { Monoinstitutional } \\
\text { 2005-2017 }\end{array}$ & NR & $60(100 \%)$ & NR & NR & NR & $\begin{array}{c}\text { Age }>60: 56.7 \% \\
\text { multiple metastatic } \\
\text { sites (bone and } \\
\text { visceral): } 61.7 \% \\
\text { multiple bone } \\
\text { metastasis: } 83.3 \% \\
\text { ECOG PS } 0-2: 70 \%\end{array}$ & NR & mOS: 9 months \\
\hline
\end{tabular}

* listed by year. Abbreviations: N: number; ECOG PS: performance status according to ECOG scale; G3: grade 3; mOS: median overall survival; SRE: skeletal-related events; NR: not reported. 
A subsequent Chinese retrospective analysis evaluated the clinicopathological characteristics of bone metastases in 66 patients with GC treated at one institution over a period of 10 years (2008-2018), representing 11.3\% of the entire metastatic GC patients population evaluated in the study (884 patients) [56]. Among them, $45.5 \%$ and $54.5 \%$ had synchronous and metachronous bone metastases, respectively. The majority of those patients were young male (68.2\%) with ECOG PS 0-1 (68.2\%), multiple metastatic sites involved (bone and visceral: $84.9 \%)$, and multiple bone metastases $(84.8 \%)$ with prevalent axial distribution (spine: $78.5 \%$; pelvic bones: $68.2 \%$; ribs: $47.0 \%$; lower extremity: $34.8 \%$; sternum: $33.3 \%$; scapula: $31.8 \%$; upper extremity: $21.2 \%$; skull: $19.7 \%$ ). However, this analysis did not report the type of metastasis (osteolytic, osteoblastic, or mixed). Finally, the majority of tumors was poor differentiated/mucinous/signet ring cells (71.2\%) and were located in the antrum $(30.3 \%)$.

Recently, another Chinese retrospective analysis showed the data from 42,966 GC collected in the American population by Surveillance, Epidemiology, and End Results (SEER) database over a period of six years (2010-2016) [57]. Of them, 1798 patients had bone involvement $(4.18 \%)$. In addition, in this case bone metastases were more commonly reported in young patients (7.3\% in 20-39 years old range), with an inverse correlation with age (5.45\% in 40-59 years older, $4.09 \%$ in $60-79$ years older, and $2.39 \%$ in $>80$ years older subgroup). Additionally, they were more common in men and in tumors showing the following characteristics: grade 3 (odd ratio (OR): 3.93, $p<0.001$ ), located to the stomach (antrum versus proximal location: $\mathrm{OR}=0.81 ; p=0.02)$, diffuse according to Lauren classification [63] (OR: 1.46, $p<0.001$ ), with signet ring cells or with nodal involvement (OR: $2.09, p<0.001)$. These data regarding tumor and patients' characteristics were consistent with those showed by Qiu MZ et al. in another retrospective analysis from the SEER database including GC treated between 2010 and 2014 [58]. Of note, Liang C et al. [56] reported that the patients who underwent to surgical resection of primary tumors had a lower incidence of bone metastases if compared to the patients who did not receive a surgical approach $(0.36 \%$ versus $7.6 \%)$. Finally, also in this case, patients with bone metastases had concurrent extra-bone metastatic sites and multiple bone sites involved. However, this analysis evaluated neither the type of the lesions and their distribution nor their onset time.

Finally, few anecdotal cases of GC patients with bone metastasis located to the bones of the hand were reported [64-68].

For a summary of the incidence of bone involvement according to different skeletal sites, see Figure 1.

Additionally, there are few reports in the literature regarding the appearance of bone lesions related to early GC $[69,70]$. When the primary tumor is an early lesion, the presence of metastases to the bone is often underdiagnosed, because bone involvement is investigated only in case of symptoms (e.g., pain). Park et al. focused on the incidence and risk factors of bone recurrence in 1683 GC patients who received a curative resection between 1989 and 2008 [71]. Therefore, this retrospective study analyzed only metachronous bone disease. The incidence of bone involvement was $1.8 \%$ in the entire study population, with a higher rate in case of advanced primary tumor at diagnosis $(0.4 \%$ in case of early GC versus $3.4 \%$ in the more advanced stages). The median time from the surgery to the detection of bone metastases was 28 months (range: 4-111 months) and the majority of patients had multiple metastases located to the axial skeleton (spine: $93.3 \%$, pelvic bone: $40 \%$ and ribs: $36.6 \%$ ). 


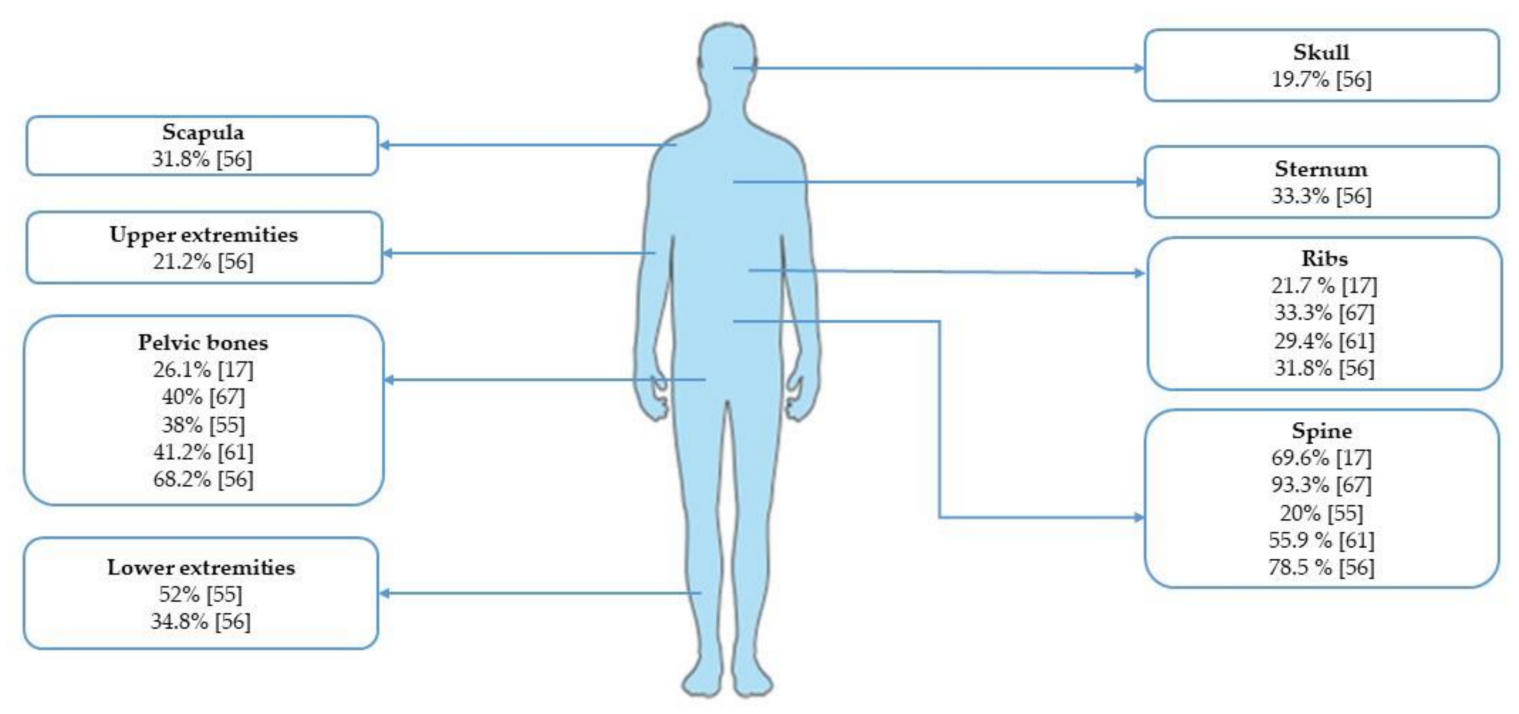

Figure 1. Incidence of bone metastases from gastric cancer according to skeletal sites.

Lastly, even if the majority of the GC recurrence occur into the first two years after curative resection, anecdotal cases of late relapses have been reported in the literature [72,73]. In particular, Iovino et al. reported the case of a 49 -year-old patient who showed a tumor relapse from GC after 11 years from the curative surgical resection [73]. The patient had severe neurological signs from a diffuse vertebral involvement and marrow infiltration without detection of any other metastatic lesions or primary tumor; the biopsy of the soft tissue near the lumbar vertebra confirmed the metastatic nature of the lesion, which spread from GC. The authors explained the long latency with the tumor dormancy theory, according to that few tumor cells could be present in the organs in a state of cell-cycle arrest; thus, there is a balance between tumor cells growth and apoptosis that could persist over many years [34]. Even if the entire process is still poorly understood, the tumor cells could reactivate after the variable time, leading to a tumor relapse.

\subsection{Prognostic Implications of Bone Metastasis in GC Patients}

Unfortunately, unlike in other types of tumors, such as renal cancer [74,75], up to date, no prospective dedicated trials regarding GC patients with bone metastases exist in the literature. Additionally, no data about the outcomes of these patients were reported in the landmark phase II and III trials in the metastatic GC setting (see above). Therefore, the most representative data regarding the prognosis of patients with GC and bone metastasis came from the same retrospective analysis already cited in the previous Section 3.1 [17,49-62] (Table 1).

More in detail, Silvestris et al. reported a median overall survival (OS) of 14 months in the entire study population ( $95 \%$ confidence interval (CI): $12-15.9$ months), with a median time of 8 months for the first diagnosis of bone involvement (95\% CI: 6.1-9.8 months) and a median OS of 6 months from that diagnosis (95\% CI: 5-6.9 months) [55]. Of note, they included in the analysis only GC patients with bone metastases who died, whereas they did not evaluate alive patients with documented metastases to the bone. Additionally, they showed that the appearance of skeletal-related events (SREs) impacts on the prognosis (for additional details regarding SRE see the next Section 4.2.2). This analysis showed that a D2 lymph node dissection was an independent prognostic factor of both shorter time to the diagnosis of bone involvement in GC patients (hazard ratio (HR): 2.7, p: 0.013) and worse survival in case of bone metastases recognition (HR: 2.285, p: 0.008). Finally, there was no difference in median OS in patients diagnosed with synchronous or metachronous bone disease ( 5 months in each subgroup). This may be related to the worse prognosis linked to the mere diagnosis of bone metastatic involvement. Finally, the authors evaluated only the 
use of zoledronic acid, whereas there is no mention of the type of chemotherapy used or its impact on survival.

Wen et al. [56] showed a median OS of 6.5 months in the entire population $(95 \% \mathrm{CI}$ : 4.2-8.7 months), with $69.7 \%, 41.5 \%$, and $13.3 \%$ patients alive at 6,12 , and 24 months, respectively. Unlike the previous Italian analysis [55], the author showed a worse OS in case of synchronous disease if compared to metachronous one (4.1 versus 11.8 months, $p=0.032$ ). Additionally, they reported a better survival in patients who had received an active chemotherapy ( $p: 0.004$ ) as well as in patients who showed a good PS ECOG (8 months versus 3.6 months in the ECOG $0-1$ and ECOG 2 subgroup, respectively; $p=0.001$ ). However, the authors did not show the type of active treatment used and the study population was deeply heterogeneous, which was mainly due to the retrospective nature of the study design and the rarity of bone involvement in metastatic GC.

The risk of developing bone metastases was higher in patients affected by metastatic GC with lung involvement $(20.24 \%$ versus $4.06 \%, p<0.001)$ as reported by Qiu et al. [58]. In this analysis, they showed a median OS of 4 months in case of bone metastases, with a case-specific survival rate of $1.27 \%$ (versus $29.86 \%$ in patients without bone involvement). Therefore, they concluded that even if it is hard to routinely assess a metastatic disease to the bone or the brain from GC, due to the rarity of their involvement and the risk of overlook, it could be feasible to evaluate those sites in patients who have risk factors (e.g., lung or liver metastasis).

The recent analysis by Liang et al. underlined the impact of surgery of the primary tumor site and of the chemotherapy on the outcome of GC patients with bone involvement [57]. In fact, they reported a median OS of 3 months in the entire study population, improved to 9 months in patients who received surgery (versus 3 months in case of no resection, HR: $0.54,95 \%$ CI: $0.40-0.72 ; p<0.001$ ) and to 7 months in patients who received chemotherapy (versus one month, $p<0.001$ ). Of note, this analysis did not show any benefit by adding radiotherapy to the treatment $(p>0.05)$. However, also in this case, the authors did not describe the type of surgery or chemotherapy used, due to the nature of the analysis (retrospective design on data collected in the SEER database). Additionally, they reported the following limitations of the analysis: the underestimation of bone involvement in GC, since they recorded only symptomatic diagnosed cases, the lack of data regarding peritoneal metastasis, and the inaccurate evaluation of death-related causes.

In conclusion, the presence of bone metastases seems to be related to worse prognosis in metastatic GC patients. However, due to the retrospective design of the analysis, the heterogeneity of the study populations, and the rarity of bone involvement, further investigations are needed in order to evaluate the prognostic role of bone metastases and to confirm these findings.

\section{Clinical Management of Metastatic Gastric Cancer Patients with Bone Involvement}

\subsection{Radiological Assessment}

Unlike others cancer types with higher incidence of bone metastases, the European Society of Medical Oncology (ESMO) [3] and National Comprehensive Cancer Network $(\mathrm{NCCN})$ guidelines [76] do not recommend skeletal screening with bone scintigraphy in patients with GC at the time of diagnosis or during treatment. Therefore, the incidence of asymptomatic bone lesions is likely underestimated, and approximately $14 \%$ of GC patients are diagnosed with bone metastasis only during autopsy [52].

Chest-abdomen-pelvis computed tomography (CT) scan is the most commonly used imaging technique in the initial diagnostic workup; however, in the follow-up setting, it is recommended only in case of symptoms suspicious for bone recurrence, such as pain [77].

The elevated serum levels of alkaline phosphatase (ALP), which is known to be the most predictive biological marker for the presence of bone metastases in GC, together with the presence of elevated tumor markers, such as carcinoembryonic antigen (CEA) and CA19-9, suggest the need for skeletal screening [78]. 
In case of recurrence of disease, it has been demonstrated that more aggressive tumor phenotypes, including the presence of lymph node metastasis, are associated with higher risk of bone recurrence. In particular, Park et al. showed that the N2/N3 stage has a risk of bone recurrence significantly higher than N0/N1 (HR: 1.44, 95\% CI: 1.217-1.694) [64]. Additionally, Liang et al. have recently described some clinical and histological features than could help the oncologists to identify the "patients with high risk of bone metastases": Gastro Esophageal Junction (GEJ) cancer, younger age, white race, poor differentiated tumor grade, higher lymph nodes stage, and diffuse histology according to Lauren classification $[57,63]$. They might suggest the use of radiological bone assessment in this population as standard at baseline.

${ }^{18}$ Fluorodeoxiglucose Positron Emission Tomography $\left({ }^{18}\right.$ FDG-PET) scan can be useful for the evaluation of lymph nodes involvement as well as for distant metastases including bone metastases. Nevertheless, it is well known that it has a lower sensitivity in GC patients with diffuse histological type, due to the lower glucose transporter 1 (GLUT1) expression in these cells [79].

Finally, the role of magnetic resonance imaging is limited to the evaluation of medullary involvement in the presence of neurological symptoms. Additionally, it is very sensitive for the study of vertebral and pelvic metastatic disease [80].

A "Tricky" Evaluation of the Response on Bone Metastases during Treatment: Focus on the Bone Flare

Patients with bone metastases from GC require periodic bone evaluation with a $\mathrm{CT}$ scan with a bone window in order to assess the response to therapy according to Response evaluation criteria in solid tumors (RECIST) 1.1 criteria [81]. Additionally, a bone scintigraphy or ${ }^{18}$ FDG-PET could be performed. However, unlike the visceral sites, the response evaluation in case of bone metastases might be difficult due to the existence of strict criteria in this setting [81] and the possibility to detect the bone flair.

The bone flare is a radiological phenomenon, which refers to an increased radiotracer uptake (i.e., $99 \mathrm{mTc}$-labeled bisphosphonates used in the bone scintigraphy) in the bones of the patients with metastatic cancer and bone metastases at baseline, despite the clinical and radiological findings of response to treatment in the other metastatic districts of the body. This phenomenon was firstly studied in prostate cancer patients in the mid-1980s [82]. Indeed, learning from the experiences in prostate cancer, a worsening in bone scan during the first months of systemic treatment for bone metastases could be caused by an intense osteoblastic response and not by a progression of disease [83]. Therefore, it is important to note that we can refer to the bone flair only in case of osteoblastic lesions, whereas an increased isotope uptake by osteolytic metastases should always be considered as a progression of disease. However, often it could be difficult to discriminate bone flare from progressive bone metastases, with a concrete risk of wrong response assessment. In prostate cancer, a prospective study on treatment-naïve metastatic patients showed that bone flare can occur in patients with positive baseline bone scan in a high percentage of cases but also in patients with no abnormalities at the scintigraphy performed at the baseline. Interestingly, these patients were confirmed to have skeletal metastases at followup [84].

Bone flare phenomenon has been also reported in other kind of tumors [85-88], including GC. Up to date, only two case reports about bone flare in GC patients have been published. More in detail, Amoroso et al. reported the case of a 43-year-old man who started chemotherapy for advanced disease. Despite of the appearance of new osteoblastic lesions, treatment was continued, and the second radiological evaluation confirmed the presence of stable osteoblastic lesions [89]. The other case is about a 54-year-old male with baseline bone metastases from GC who showed an increased intensity at bone scan after three cycles of chemotherapy, despite an improvement in skeletal pain. Nevertheless, after additional three cycles of chemotherapy, the bone scan revealed a decrease in the intensity of the signal in the same areas [90]. 
In conclusion, even if rare, bone flare should be taken into account in metastatic GC patients with osteoblastic lesions who show progression of disease only to the skeleton. In these cases, especially if the patients do not show a clinical worsening, the clinicians should be aware about this phenomenon, since it could be misinterpreted as progression of disease, leading to a change in the chemotherapy regimen. Therefore, a multidisciplinary framework in distinguishing the two conditions is critical also in GC patients.

\subsection{How to Treat Metastatic Gastric Cancer Patients with Bone Metastases}

The treatment of GC patients with metastases to the skeleton can be distinguished into two areas: treatment of metastatic GC disease per se and bone-related treatments.

\subsubsection{Systemic Treatments}

According to international guidelines [3,76], palliative chemotherapy-with or without targeted agents-is the standard of care in the treatment of metastatic GC. In fact, surgery is not an option in case of metastatic disease, especially to the bone. A detailed description of the currently recommended treatments for metastatic GC disease and/or future perspectives is not in the aim of this review; however, you can refer to dedicated literature and guidelines [3-5,12,76] for detailed coverage.

To date, there is a lack of specific data regarding bone involvement in the landmark phase II and III trials in GC. In fact, among $\approx 50$ clinical trials investigating the role of chemotherapy, target therapies, and immunotherapies in advanced GC (first-, second-, $\geq$ third lines) over the last two decades, only seven trials showed specific data for GC patients with skeletal metastases (Table 2).

In particular, among chemotherapy trials, in 2008, Al-Batran $S$ et al. compared the efficacy of FLO (fluorouracil, leucovorin, and oxaliplatin) and FLP (fluorouracil, leucovorin, and cisplatin) regimen as first-line treatment for 220 metastatic GC patients, reporting the data of $6.8 \%$ of patients with bone involvement [91]. However, the trial did not show the subgroup analysis for those patients and did not report the outcomes accordingly. In 2009, the non-inferiority phase III ML17032 trial, which compared CX (cisplatin and capecitabine) versus CF (cisplatin and fluorouracil) as first-line treatment in 316 metastatic GC patients, showed a bone involvement in $6.3 \%$ of patients; additionally, the authors evaluated the impact of bone metastases on survival outcome (subgroup analysis), showing a benefit by using the CX regimen in these patients (see Table 2 for additional details) [92]. Finally, the phase III SOS trial reported 3.2\% prevalence of bone metastases in 625 Asian patients receiving Cisplatin $+\mathrm{S}-1$ every five weeks versus $C$ isplatin $+\mathrm{S}-1$ every three weeks as first-line treatment [93]. However, no data regarding the impact of bone involvement on the prognosis were shown in this trial as well.

The Korean trial is the only second-line chemotherapy trial reporting the rate of bone involvement in the study population (6\%) [94]. No data about the prognosis are available from this trial.

In the context of target therapies trials, the AVATAR [95] and INTEGRATE [96] are the only studies reporting the rate of skeletal metastases. The phase III AVATAR trial investigated the efficacy of the addition of bevacizumab (anti-vascular endothelial growth factor agent) to chemotherapy (CX regimen) as first-line treatment in 202 Asian patients with metastatic GC [95]. The phase II INTEGRATE trial evaluated the activity of regorafenib versus best supportive care as second or third-line treatment for 147 metastatic GC patients [96]. The trials showed that 3.5\% [95] and 10.8\% [96] of patients had metastatic bone disease, respectively. However, unfortunately, there are no data regarding the prognostic effect of bone involvement in both trials.

Regarding the trials investigating the role of immunotherapy in metastatic GC, the Asian phase III ATTRACTION-2 trial, which tested the efficacy of nivolumab in highly pretreated patients, is the only one showing data about the rate of bone metastases $(2.2 \%)[97,98]$. However, also in this case, no data about the outcomes are available for these patients. 
Table 2. Data regarding bone metastases according to the landmark phase II/III trials in metastatic gastric cancer.

\begin{tabular}{|c|c|c|c|c|c|c|c|}
\hline $\begin{array}{l}\text { Trial and Year of } \\
\text { Publication }\end{array}$ & Phase & Setting & $N$ Patients & $\begin{array}{l}\text { Type of Metastatic Sites } \\
\text { Reported (\% of Patients) }\end{array}$ & $\begin{array}{c}\text { N Patients with } \\
\text { Bone Metastases (\%) }\end{array}$ & $\begin{array}{c}\text { Arms and } \\
\text { Eventual Target }\end{array}$ & $\begin{array}{l}\text { Outcomes in Patients } \\
\text { with Bone Metastases }\end{array}$ \\
\hline \multicolumn{8}{|c|}{ Chemotherapy * } \\
\hline V325 trial, 2006 [99] & III & First line & 445 & NR & NR & TCF versus CF & NR \\
\hline REAL-2, 2008 [101] & III & First-line & 1002 & NR & NR & $\begin{array}{l}\text { ECF/ECX versus } \\
\text { EOF/EOX } \\
\text { (non-inferiority) }\end{array}$ & NR \\
\hline Al-Batran et al., 2008 [91] & III & First-line & 220 & $\begin{array}{c}\text { Lung: } 12.7 \% \text {; Liver: } 50.4 \% \text {; } \\
\text { Lymph node: } 47.7 \% \text {; } \\
\text { Peritoneum: } 30.4 \% \text {; Pleura: } 8.1 \% \text {; } \\
\text { Other: } 28.6 \%\end{array}$ & $14(6.8 \%)$ & FLO versus FLP & NR \\
\hline ML17032, 2009 [92] & III & First line & 316 & $\begin{array}{l}\text { Lung: } 7.9 \% \text {; Liver: } 48.4 \% \text {; } \\
\text { Peritoneum: } 18.7 \% \text {; Pleura: } 3.1 \% \text {; } \\
\text { Soft tissue: } 3.8 \% \text {; Skin: } 0.6 \%\end{array}$ & $20(6.3 \%)$ & $\begin{array}{l}\mathrm{CX} \text { versus } \mathrm{CF} \\
\text { (non-inferiority) }\end{array}$ & $\begin{array}{l}\text { OS: Bone metastases: HR: } \\
\text { 1, no bone: } \mathrm{HR} \approx 0.8 \\
\quad \text { (favor } \mathrm{CX} \text { ) } \\
\text { PFS: Bone metastases: } \\
\mathrm{HR} \approx 0.6 \text {, no bone: HR } \\
\approx 0.85 \text { (favor } \mathrm{CX} \text { ) }\end{array}$ \\
\hline $\begin{array}{l}\text { GC0301/TOP-002 trial, } 2011 \\
\text { [103] }\end{array}$ & III & First line & 326 & Liver: 33.7\%; Peritoneum: 32.2\% & NR & $\begin{array}{l}\text { S-1 versus S-1+ } \\
\text { irinotecan }\end{array}$ & NR \\
\hline FFCD trial, 2014 [104] & III & First line & 416 & NR & NR & ECX versus Folfiri & NR \\
\hline Yamada et al., 2015 [105] & III & First line & 685 & $\begin{array}{l}\text { Lung: } 10.3 \% \text {; Liver: } 36.9 \% \text {; } \\
\text { Lymph node: } 84.2 \% ; \\
\text { Peritoneum: } 18.2 \%\end{array}$ & NR & $\begin{array}{l}\text { Oxaliplatin+S-1 versus } \\
\text { Cisplatin+S-1 } \\
\text { (non-inferiority) }\end{array}$ & NR \\
\hline $\begin{array}{l}\text { SOS trial, } 2015 \\
{[93]}\end{array}$ & III & First line & 625 & $\begin{array}{c}\text { Lung: } 6.8 \% \text {; Liver: } 35.3 \% \text {; } \\
\text { Lymph node: } 67.7 \% \text {; } \\
\text { Peritoneum: } 37.3 \%\end{array}$ & $20(3.2 \%)$ & $\begin{array}{l}\text { Cisplatin+S-1 q5 weeks } \\
\text { versus q3 weeks }\end{array}$ & NR \\
\hline AIO, $2011[106]$ & III & $\begin{array}{l}\text { Second } \\
\text { line }\end{array}$ & 40 & $\begin{array}{c}\text { Lung: } 10 \% \text {; Liver: } 45 \% \text {; Lymph } \\
\text { node: } 35 \% \text {; Peritoneum: } 45 \% \text {; } \\
\text { Other: } 35 \%\end{array}$ & NR & Irinotecan versus BSC & NR \\
\hline
\end{tabular}


Table 2. Cont.

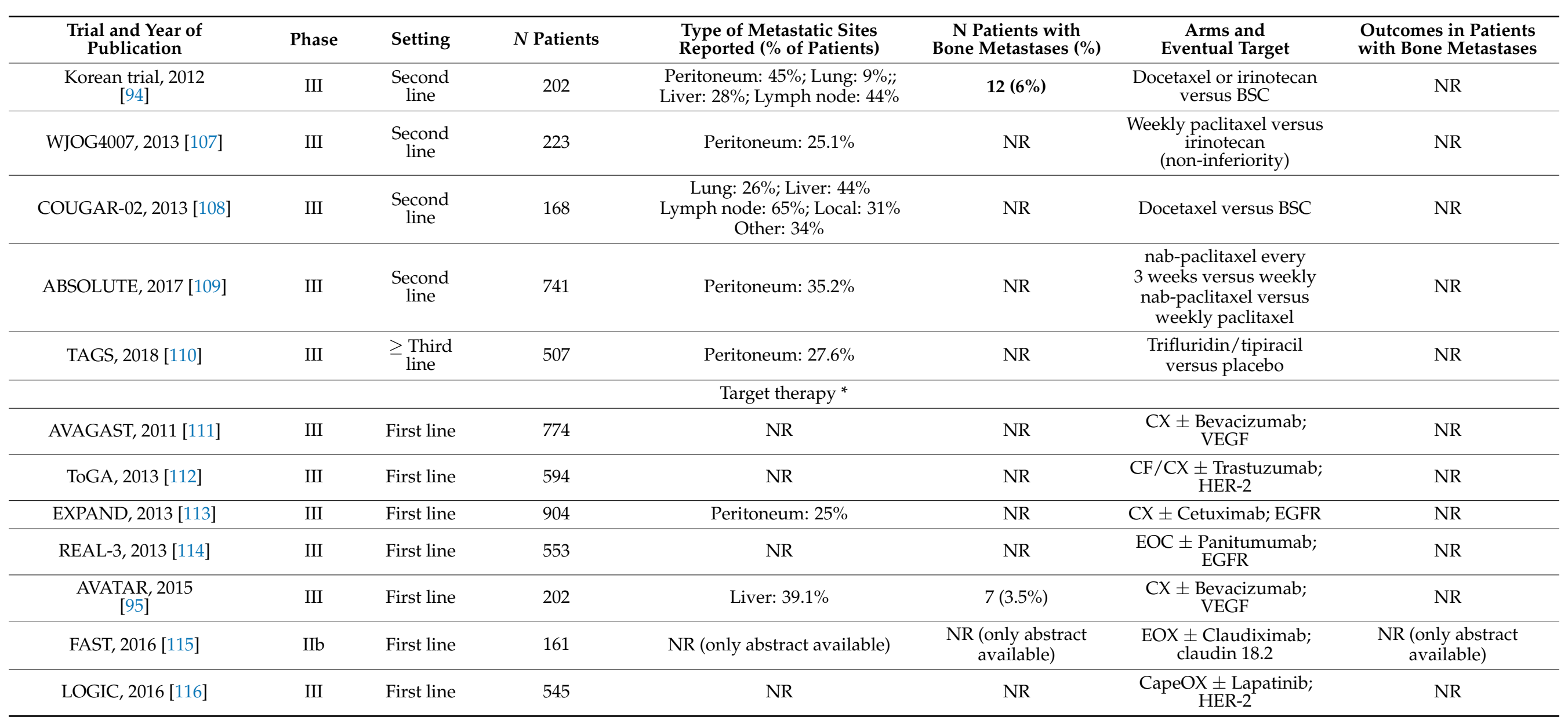


Table 2. Cont

\begin{tabular}{|c|c|c|c|c|c|c|c|}
\hline $\begin{array}{c}\text { Trial and Year of } \\
\text { Publication }\end{array}$ & Phase & Setting & $N$ Patients & $\begin{array}{l}\text { Type of Metastatic Sites } \\
\text { Reported (\% of Patients) }\end{array}$ & $\begin{array}{c}\text { N Patients with } \\
\text { Bone Metastases (\%) }\end{array}$ & $\begin{array}{c}\text { Arms and } \\
\text { Eventual Target }\end{array}$ & $\begin{array}{l}\text { Outcomes in Patients } \\
\text { with Bone Metastases }\end{array}$ \\
\hline METGastric, 2017 [117] & III & First line & 562 & NR & NR & $\begin{array}{c}\text { Folfox } \pm \text { Onartuzumab; } \\
\text { MET }\end{array}$ & NR \\
\hline RILOMET-1, 2017 [118] & III & First line & 609 & Liver: $41.7 \%$ & NR & $\begin{array}{l}\text { ECX } \pm \text { Rilotumumab; } \\
\text { MET }\end{array}$ & NR \\
\hline HELOISE, 2017 [119] & $\mathrm{IIIb}$ & First line & 248 & NR & NR & $\begin{array}{c}\mathrm{CF} / \mathrm{CX}+\text { trastuzumab } \\
\text { (two doses as } \\
\text { mantainance); HER-2 }\end{array}$ & NR \\
\hline RAINFALL, 2019 [121] & III & First line & 645 & Peritoneum: 37.4\%; Liver: 29.3\% & NR & $\begin{array}{c}\text { CF/CX+ ramucirumab; } \\
\text { VEGFR-2 }\end{array}$ & NR \\
\hline GRANITE-1, 2013 [122] & III & $\begin{array}{l}\text { Second } \\
\text { line } \\
\text { Third line }\end{array}$ & 656 & Lung: $19.6 \%$; Liver: $45.5 \%$ & NR & $\begin{array}{l}\text { Everolimus versus } \\
\text { placebo; mTOR }\end{array}$ & NR \\
\hline REGARD, 2014 [123] & III & $\begin{array}{l}\text { Second } \\
\text { line }\end{array}$ & 355 & Peritoneum: $30.7 \%$ & NR & $\begin{array}{l}\text { Ramucirumab versus } \\
\text { Placebo; VEGFR-2 }\end{array}$ & NR \\
\hline RAINBOW, 2014 [124] & III & $\begin{array}{l}\text { Second } \\
\text { line }\end{array}$ & 665 & Peritoneum: $47.3 \%$ & NR & $\begin{array}{c}\text { Paclitaxel } \pm \\
\text { Ramucirumab; VEGFR-2 }\end{array}$ & NR \\
\hline TyTAN, 2014 [125] & III & $\begin{array}{l}\text { Second } \\
\text { line }\end{array}$ & 261 & No visceral: $98.8 \%$ & NR & $\begin{array}{c}\text { Paclitaxel } \pm \text { Lapatinib; } \\
\text { HER-2 }\end{array}$ & NR \\
\hline $\begin{array}{c}\text { INTEGRATE, } 2016 \\
\text { [96] }\end{array}$ & II & $\begin{array}{l}\text { Second } \\
\text { line } \\
\text { Third line }\end{array}$ & 147 & $\begin{array}{c}\text { Lung: } 20.4 \% \text {; Liver: } 53.7 \% \\
\text { Lymph node: } 51 \% \text {; Peritoneum: } \\
\text { 32\%; Other: } 36 \%\end{array}$ & $16(10.8 \%)$ & $\begin{array}{l}\text { Regorafenib versus } \\
\text { placebo; multikinase } \\
\text { inhibitor }\end{array}$ & NR \\
\hline SHINE, 2017 [126] & II & $\begin{array}{l}\text { Second } \\
\text { line }\end{array}$ & 71 & $\begin{array}{c}\text { Liver: } 56.3 \% \text {; Lung: } 21.1 \% \\
\text { Peritoneum: } 25.4 \% \\
\text { Lymph nodes: } 54.9 \%\end{array}$ & NR & $\begin{array}{c}\text { Paclitaxel } \pm \text { AZD4546; } \\
\text { FGFR-2 }\end{array}$ & NR \\
\hline GATSBY, 2017 [127] & $\mathrm{II} / \mathrm{III}$ & $\begin{array}{l}\text { Second } \\
\text { line }\end{array}$ & 345 & Visceral (lung or liver): $100 \%$ & NR & $\begin{array}{c}\text { Taxanes } \pm \text { TDM-1; } \\
\text { HER-2 }\end{array}$ & NR \\
\hline GOLD, 2017 [128] & III & $\begin{array}{l}\text { Second } \\
\text { line }\end{array}$ & 643 & NR & NR & $\begin{array}{c}\text { paclitaxel } \pm \text { olaparib; } \\
\text { PARP }\end{array}$ & NR \\
\hline
\end{tabular}


Table 2. Cont.

\begin{tabular}{|c|c|c|c|c|c|c|c|}
\hline $\begin{array}{c}\text { Trial and Year of } \\
\text { Publication }\end{array}$ & Phase & Setting & $N$ Patients & $\begin{array}{l}\text { Type of Metastatic Sites } \\
\text { Reported (\% of Patients) }\end{array}$ & $\begin{array}{c}\text { N Patients with } \\
\text { Bone Metastases (\%) }\end{array}$ & $\begin{array}{c}\text { Arms and } \\
\text { Eventual Target }\end{array}$ & $\begin{array}{l}\text { Outcomes in Patients } \\
\text { with Bone Metastases }\end{array}$ \\
\hline ANGEL, 2019 [129] & III & $\geq$ Third & 460 & NR & NR & $\begin{array}{l}\text { Rivoceranib (apatinib) } \\
\text { versus best supportive } \\
\text { care; VEGFR-2 }\end{array}$ & NR (abstract only) \\
\hline $\begin{array}{c}\text { DESTINY-Gastric 01, } 2020 \\
\text { [130] }\end{array}$ & II & $\geq$ Third & 187 & NR & NR & $\begin{array}{c}\text { Trastuzumab deruxtecan } \\
\text { versus chemotherapy } \\
\text { (paclitaxel or irinotecan); } \\
\text { HER-2 }\end{array}$ & NR \\
\hline \multicolumn{8}{|c|}{ Immunotherapy (single agent and combinations) * } \\
\hline Janjigian et al., 2020 [131] & II & First line & 37 & NR & NR & $\begin{array}{c}\text { CF/CX or Folfox/Xelox } \\
\text { + pembrolizumab + } \\
\text { trastuzumab; PD-1, } \\
\text { HER-2 }\end{array}$ & NR \\
\hline KEYNOTE-062, 2020 [7] & III & First line & 763 & NR & NR & $\begin{array}{c}\mathrm{CF} / \mathrm{CX} \pm \\
\text { pembrolizumab or } \\
\text { pembrolizumab; PD-1 }\end{array}$ & NR \\
\hline CHECKMATE 649, 2020 [6] & III & First line & 1581 & NR (only abstract available) & $\begin{array}{l}\text { NR (only abstract } \\
\text { available) }\end{array}$ & $\begin{array}{c}\text { Folfox/Xelox } \pm \\
\text { nivolumab; PD-1 }\end{array}$ & $\begin{array}{l}\text { NR (only abstract } \\
\text { available) }\end{array}$ \\
\hline KEYNOTE-590, 2020 [133] & III & First line & 749 & NR (only abstract available) & $\begin{array}{l}\text { NR (only abstract } \\
\text { available) }\end{array}$ & $\begin{array}{l}\mathrm{CF} \pm \text { pembrolizumab; } \\
\mathrm{PD}-1\end{array}$ & $\begin{array}{c}\text { NR (only abstract } \\
\text { available) }\end{array}$ \\
\hline JAVELIN-100, 2020 [134] & III & $\begin{array}{l}\text { First line } \\
\text { mainte- } \\
\text { nance }\end{array}$ & 805 & NR & NR & $\begin{array}{l}\text { Folfox/Xelox versus } \\
\text { avelumab; PD-L1 }\end{array}$ & NR \\
\hline EPOC1706, 2020 [135] & II & $\begin{array}{l}\text { First line } \\
\text { Second } \\
\text { line }\end{array}$ & 29 & $\begin{array}{l}\text { Lymph node: } 90 \% \text {; Liver: } 45 \% \\
\text { Lung: 10\%; Peritoneum: } 31 \%\end{array}$ & NR & $\begin{array}{c}\text { Lenvatinib + } \\
\text { pembrolizumab; TKI, } \\
\text { PD-1 }\end{array}$ & NR \\
\hline KEYNOTE-061, 2018 [136] & III & $\begin{array}{l}\text { Second } \\
\text { line }\end{array}$ & 592 & Peritoneum: $28 \%$ & NR & $\begin{array}{c}\text { Paclitaxel versus } \\
\text { pembrolizumab; PD-1 }\end{array}$ & NR \\
\hline
\end{tabular}


Table 2. Cont

\begin{tabular}{|c|c|c|c|c|c|c|c|}
\hline $\begin{array}{c}\text { Trial and Year of } \\
\text { Publication }\end{array}$ & Phase & Setting & $N$ Patients & $\begin{array}{l}\text { Type of Metastatic Sites } \\
\text { Reported (\% of Patients) }\end{array}$ & $\begin{array}{c}\text { N Patients with } \\
\text { Bone Metastases (\%) }\end{array}$ & $\begin{array}{c}\text { Arms and } \\
\text { Eventual Target }\end{array}$ & $\begin{array}{l}\text { Outcomes in Patients } \\
\text { with Bone Metastases }\end{array}$ \\
\hline $\begin{array}{c}\text { ATTRACTION-2, } 2017 \\
\text { [97] }\end{array}$ & III & $\geq$ Third & 493 & $\begin{array}{l}\text { Liver: } 21.5 \% \text {; Lung: } 4.9 \% \\
\text { Peritoneum: } 21.3 \% \text {; Lymph } \\
\text { nodes: } 85.8 \% \text {; Pleural: } 1.2 \% \text {; } \\
\text { Adrenal: } 0.2 \% \text {; Other: } 10.7 \%\end{array}$ & $11(2.2 \%)$ & $\begin{array}{l}\text { Nivolumab versus } \\
\text { placebo; PD-1 }\end{array}$ & NR \\
\hline JAVELIN-300, 2018 [137] & III & $\geq$ Third & 371 & NR & NR & $\begin{array}{c}\text { Chemotherapy } \\
\text { (paclitaxel or irinotecan) } \\
\text { versus avelumab; PD-L1 }\end{array}$ & NR \\
\hline KEYNOTE-059, 2019 [138] & II & $\begin{array}{l}\geq \text { Third } \\
\text { line }\end{array}$ & 259 & Peritoneum: $1.5 \%$ & NR & Pembrolizumab; PD-1 & NR \\
\hline
\end{tabular}

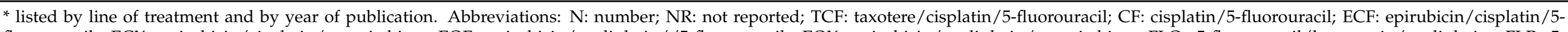

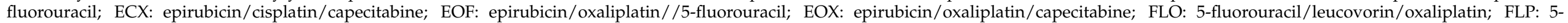

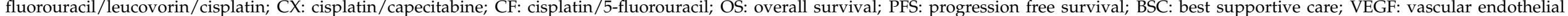

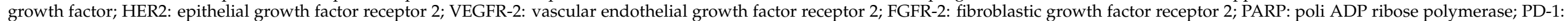
programmed death 1; PD-L1: programmed death ligand 1; TKI: tyrosine kinase inhibitor. 
In conclusion, even if retrospective evidence seems to suggest a possible worse prognosis in patients with metastatic GC and bone disease, there are no randomized prospective trials confirming these findings. Additionally, no specific data regarding targeted-bone treatments in metastatic GC are available. Therefore, to date, the treatment of metastatic disease does not change according to the metastatic sites involved $[3,76]$. In particular, the data regarding the impact on bone involvement as well as the response of bone metastases to chemotherapy are limited, and further evaluations about the molecular mechanisms and landscape of bone invasions are needed in order to design specific trials. A multidisciplinary management of those patients, including bone-related treatments, is mandatory in order to palliate the symptoms and to preserve a good PS.

\subsubsection{Skeletal-Related Events and Bone-Related Treatments}

In general, the presence of bone metastases causes a reduction of physical functions of the patients and deterioration of their quality of life (QoL), especially in case of axial skeleton involvement with multiple osteolytic lesions. In fact, they are often the cause of consistent bone pain that requires opioid-based therapy [139]. Additionally, the presence of bone metastases results in significant morbidity for the patients, mainly because of the associated SREs, which are defined as "pathologic fractures, the need for radiotherapy or surgical interventions to treat or prevent an impending fracture, spinal cord compressions, and hypercalcemia" [59].

In the largest multicenter retrospective study on bone metastases in GC, $31 \%$ of patients with skeletal involvement experienced at least one SRE [55]. In this analysis, radiotherapy treatment of the bone lesions was the most common SRE ( $47.1 \%$ of all events), followed by pathologic fracture $(22.4 \%)$, surgery to the bone sites $(15.3 \%)$, spinal cord compression $(10.6 \%)$, and hypercalcemia $(4.7 \%)$.

Regarding the prognostic value of SREs, median survival in the whole population was 3 months after the development of the first SRE (versus 5 months in patients without SREs), suggesting that the poor prognosis of these patients is related not only to the presence of bone disease per se but also to the appearance of SREs.

Therefore, the bone-targeted treatments are important as well as the systemic therapies in order to improve the outcomes for metastatic patients, allowing them to control pain and to maintain a good PS and eventually receive multiple lines of treatment for metastatic disease ("continuum of care" concept). In this context, radiotherapy, surgery, and drug therapies represent the main options; there is no difference in those treatments according to the primary tumor site (e.g., prostate, breast, gastric, etc.) [140].

The use of radiotherapy has been shown to be very effective to control pain-especially with a neuropathic component-in patients with bone metastases after failure of or intolerance to opioid-based therapy as well as to prevent impending fractures. Several randomized trials have been conducted to assess the fraction schedule of the palliative radiotherapy; based on these analyses and a systematic review [141], a single dose of 8 Gy seems to be the best option for patients with poor prognosis, especially if they have vertebral involvement.

In selected cases, also, orthopedic surgery and neurosurgery can help to improve the QoL of these patients, to control incoercible pain, to prevent long bones and vertebral impending fractures and spinal cord compression.

The role of "bone-focused" drugs has been defined in the last years. Bisphosphonates and RANK-L inhibitors are the most important agents in this field. Bisphosphonates-based treatments, such as zoledronic acid at the dose of $4 \mathrm{mg}$ every 3 or 4 weeks as intravenous infusion, is able to modify the bone homeostasis, with the inhibition of osteoclast-mediated bone resorption; they are useful to prevent and delay SREs in solid tumors, including GC [142]. Silvestris et al. showed a significant extension of the time to the first SRE and an increase in the median survival by using zoledronic acid after the diagnosis of bone metastases in GC patients [55]. These interesting retrospective data may support the beneficial effects of zoledronic acid in GC patients with bone involvement, especially in 
case of osteolytic lesions. However, further prospective analyses are needed in order to confirm this assumption. Denosumab is a well-studied agent among RANK-L inhibitors. Recently, a combined analysis of three randomized phase III trials has shown that the receptor activator of NF- $\mathrm{kB}$ ligand inhibitor Denosumab-used at the dose of $120 \mathrm{mg}$ as subcutaneous injection every 4 weeks-is superior to zoledronic acid in delaying the time to first SRE appearance and in reducing the risk of SRE itself, also in patients with bone metastases caused by cancers different from breast, prostate, lung, and kidney [143]. The optimal duration of treatment with bone-related drugs is not well-established.

Another important issue in the management of bone metastases is the risk of hypercalcemia. In this case, the patient should receive a medical treatment according to guidelines for hypercalcemia stratified for serum calcium levels [144].

Finally, the "hungry bone" syndrome is worth mentioning. This syndrome typically occurs after curative surgery for hyperparathyroidism [145]. However, it could be diagnosed also in anecdotal cases of osteoblastic bone metastases by the occurrence of severe hypocalcemia, which is mainly related to excessive calcium apposition into the osteoblastic massive lesions. Recently, Sakai et al. reported the case of an 87-year-old man diagnosed with GC and bone involvement due to the appearance of hypocalcemia [146]. The treatment of the hungry bone syndrome is the correction of hypocalcemia.

In conclusion, although there are limited evidences regarding the efficacy of zoledronic acid and denosumab in patients with bone metastases from GC, the use of these drugs could be helpful also in GC in order to control the spread of the disease, to improve the life expectancy and QoL, and to reduce the probability of occurrence of SREs. Since no specific data are available up to date, the choice of the best drug should be based on the cost-benefit ratio and toxicity profile.

\section{Conclusions and Future Perspectives}

GC is a very heterogeneous disease; this quite recent concept has become diffusely accepted today. However, the journey to discover the molecular mechanisms that control GC behavior has just started. Recently, the molecular classifications of GC have depicted a very complex landscape $[13,14]$ and multiple molecules, which could be eventually targeted by specific treatments, have been identified [4,5]. Among those molecules, the investigation regarding the role of antiangiogenic agents and multikinase inhibitors, such as cabozantinib, might be interesting future frontiers in the control of bone metastasis also in GC, as shown in other types of tumors, such as renal cancer [147]. However, at the moment, these classifications are hardly applicable in clinical practice. Additionally, there is a lack of knowledge about the molecular mechanisms that control the process of GC metastatization.

In this context, the bone metastases from GC represent still a challenge for the research in this field. In fact, they are rare and often underdiagnosed due to the lack of specific recommendation for their detection according to international guidelines [3,76]. However, bone involvement should be evaluated not only in patients with bone pain or neurological symptoms but also in metastatic GC patients with risk factors, such as aggressive disease or lung metastases. Additionally, there is a lack of prospective evidences regarding specific treatments for patients with bone metastases as well as data showing the outcomes of patients with skeletal metastases from GC or the response of those lesions to standard therapies. Therefore, since the majority of the data in the literature are retrospective and based on a very heterogeneous populations, further prospective studies are needed in order to define the best treatment for GC with bone metastases. Additionally, a better understanding of the underlying molecular mechanisms, by analyzing tumor cells as well as inflammatory tumor infiltrating cells or bone matrix compounds into the bone lesions specimens, could be useful in order to design specific trials.

Author Contributions: Conceptualization, A.P. (Angelica Petrillo); Topic, A.P. (Angelica Petrillo), D.B.; resources, A.P. (Angelica Petrillo), E.F.G., A.P. (Annalisa Pappalardo); writing-original draft preparation, A.P. (Angelica Petrillo), E.F.G., A.P. (Annalisa Pappalardo); writing of particular sections: 
all authors; writing—review and editing, all authors; supervision, A.P. (Angelica Petrillo), B.D., L.A., C.C., A.D., A.F., T.F., P.G., M.O., M.R., A.S., P.F. All authors have read and agreed to the published version of the manuscript.

Funding: This research received no external funding.

Institutional Review Board Statement: Not applicable.

Informed Consent Statement: Not applicable.

Data Availability Statement: Not applicable.

Conflicts of Interest: Angelica Petrillo received personal fee from Eli-Lilly, Servier and MSD; EFG had personal fees from Novartis; L.A. received personal fee from GSK; A.D. received personal fees from Roche, Gentili, Italfarmaco, Ipsen, Novartis; B.D. received personal fee from Ipsen, Eisai, Eli Lilly, Astra Zeneca, Sanofi, MSD, Bayer, Roche, Amgen. No fees are connected with the submitted paper. The other authors declare no conflict of interest. The funders had no role in the design, writing of the manuscript, or in the decision to publish the paper.

\section{References}

1. Bray, F.; Ferlay, J.; Soerjomataram, I.; Siegel, R.L.; Torre, L.A.; Jemal, A. Global cancer statistics 2018: GLOBOCAN estimates of incidence and mortality worldwide for 36 cancers in 185 countries. CA Cancer J. Clin. 2018, 68, 394-424. [CrossRef]

2. Surveillance, Epidemiology, and End Results (SEER) Database. Available online: https://seer.cancer.gov/statfacts/html/stomach. $\mathrm{html}$ (accessed on 19 December 2020).

3. Smyth, E.C.; Verheij, M.; Allum, W.; Cunningham, D.; Cervantes, A.; Arnold, D.; ESMO Guidelines Committee. Gastric cancer: ESMO Clinical Practice Guidelines for diagnosis, treatment and follow-up. Ann. Oncol. 2016, 27 (Suppl. S5), v38-v49. [CrossRef]

4. Tirino, G.; Pompella, L.; Petrillo, A.; Laterza, M.M.; Pappalardo, A.; Caterino, M.; Orditura, M.; Ciardiello, F.; Galizia, G.; De Vita, F. What's New in Gastric Cancer: The Therapeutic Implications of Molecular Classifications and Future Perspectives. Int. J. Mol. Sci. 2018, 19, 2659. [CrossRef] [PubMed]

5. Gambardella, V.; Fleitas, T.; Tarazona, N.; Papaccio, F.; Huerta, M.; Roselló, S.; Gimeno-Valiente, F.; Roda, D.; Cervantes, A. Precision Medicine to Treat Advanced Gastroesophageal Adenocarcinoma: A Work in Progress. J. Clin. Med. 2020, 9, 3049. [CrossRef]

6. Moehler, M.; Shitara, K.; Garrido, M.; Salman, P.; Shen, L.; Wyrwicz, L.; Yamaguchi, K.; Skoczylas, T.; Bragagnoli, A.C.; Liu, T.; et al. LBA6_PR Nivolumab (nivo) plus chemotherapy (chemo) versus chemo as first-line (1L) treatment for advanced gastric cancer/gastroesophageal junction cancer (GC/GEJC)/esophageal adenocarcinoma (EAC): First results of the CheckMate 649 study. Ann. Oncol. 2020, 31 (Suppl. S4), S1142-S1215. [CrossRef]

7. Shitara, K.; Van Cutsem, E.; Bang, Y.-J.; Fuchs, C.; Wyrwicz, L.; Lee, K.-W.; Kudaba, I.; Garrido, M.; Chung, H.C.; Lee, J.; et al. Efficacy and Safety of Pembrolizumab or Pembrolizumab Plus Chemotherapy vs Chemotherapy Alone for Patients with First-line, Advanced Gastric Cancer: The KEYNOTE-062 Phase 3 Randomized Clinical Trial. JAMA Oncol. 2020, 6, 1571-1580. [CrossRef]

8. Boku, N.; Ryu, M.H.; Oh, D.; Oh, S.C.; Chung, H.C.; Lee, K.; Omori, T.; Shitara, K.; Sakuramoto, S.; Chung, I.J.; et al. LBA7_PRNivolumab plus chemotherapy versus chemotherapy alone in patients with previously untreated advanced or recurrent gastric/gastroesophageal junction (G/GEJ) cancer: ATTRACTION-4 (ONO-4538-37) study. Ann. Oncol. 2020, 31 (Suppl. S4), S1142-S1215. [CrossRef]

9. Fanotto, V.; Fornaro, L.; Bordonaro, R.; Rosati, G.; Rimassa, L.; Di Donato, S.; Santini, D.; Tomasello, G.; Leone, F.; Silvestris, N.; et al. Second-line treatment efficacy and toxicity in older vs. non-older patients with advanced gastric cancer: A multicentre real-world study. J. Geriatr. Oncol. 2019, 10, 591-597. [CrossRef] [PubMed]

10. Davidson, M.; Cafferkey, C.; Goode, E.F.; Kouvelakis, K.; Hughes, D.; Reguera, P.; Kalaitzaki, E.; Peckitt, C.; Rao, S.; Watkins, D.; et al. Survival in Advanced Esophagogastric Adenocarcinoma Improves With Use of Multiple Lines of Therapy: Results From an Analysis of More Than 500 Patients. Clin. Color. Cancer 2018, 17, 223-230. [CrossRef] [PubMed]

11. Antoniotti, C.; Moretto, R.; Rossini, D.; Masi, G.; Falcone, A.; Cremolini, C. Treatments after first progression in metastatic colorectal cancer. A literature review and evidence-based algorithm. Cancer Treat. Rev. 2020, 92, 102135. [CrossRef]

12. Smyth, E.C.; Nilsson, M.; Grabsch, H.I.; van Grieken, N.C.; Lordick, F. Gastric cancer. Lancet 2020, 396, 635-648. [CrossRef]

13. Cancer Genome Atlas Research Network. Comprehensive molecular characterization of gastric adenocarcinoma. Nature 2014, 513, 202-209. [CrossRef]

14. Cristescu, R.; Lee, J.; Nebozhyn, M.; Kim, K.-M.; Ting, J.C.; Wong, S.S.; Liu, J.; Yue, Y.G.; Wang, J.; Yu, K.; et al. Molecular analysis of gastric cancer identifies subtypes associated with distinct clinical outcomes. Nat. Med. 2015, 21, 449-456. [CrossRef]

15. Petrillo, A.; Smyth, E.C. Biomarkers for Precision Treatment in Gastric Cancer. Visc. Med. 2020, 36, 364-372. [CrossRef] [PubMed]

16. Chau, I.; Norman, A.R.; Cunningham, D.; Waters, J.S.; Oates, J.; Ross, P.J. Multivariate prognostic factor analysis in locally advanced and metastatic esophago-gastric cancer-Pooled analysis from three multicenter, randomized, controlled trials using individual patient data. J. Clin. Oncol. 2004, 22, 2395-2403. [CrossRef] [PubMed]

17. Yoshikawa, K.; Kitaoka, H. Bone metastasis of gastric cancer. Jpn. J. Surg. 1983, 13, 173-176. [CrossRef] [PubMed] 
18. Shupp, A.B.; Kolb, A.D.; Mukhopadhyay, D.; Bussard, K.M. Cancer Metastases to Bone: Concepts, Mechanisms, and Interactions with Bone Osteoblasts. Cancers 2018, 10, 182. [CrossRef]

19. Turajlic, S.; Xu, H.; Litchfield, K.; Rowan, A.; Chambers, T.; Lopez, J.I.; Nicol, D.; O’Brien, T.; Larkin, J.; Horswell, S.; et al. Tracking Cancer Evolution Reveals Constrained Routes to Metastases: TRACERx Renal. Cell 2018, 173, 581-594.e12. [CrossRef]

20. Capulli, M.; Paone, R.; Rucci, N. Osteoblast and osteocyte: Games without frontiers. Arch. Biochem. Biophys. 2014, 561, 3-12. [CrossRef]

21. Florencio-Silva, R.; Sasso, G.R.; Sasso-Cerri, E.; Simões, M.J.; Cerri, P.S. Biology of Bone Tissue: Structure, Function, and Factors That Influence Bone Cells. BioMed Res. Int. 2015, 2015, 421746. [CrossRef]

22. Guise, T.A.; Yin, J.J.; Taylor, S.D.; Kumagai, Y.; Dallas, M.; Boyce, B.F.; Yoneda, T.; Mundy, G.R. Evidence for a causal role of parathyroid hormone-related protein in the pathogenesis of human breast cancer-mediated osteolysis. J. Clin. Investig. 1996, 98, 1544-1549. [CrossRef]

23. Boyce, B.F.; Xing, L. Biology of RANK, RANKL, and osteoprotegerin. Arthritis Res. Ther. 2007, 9 (Suppl. S1), S1. [CrossRef]

24. Armstrong, A.P.; Tometsko, M.E.; Glaccum, M.; Sutherland, C.L.; Cosman, D.; Dougall, W.C. A RANK/TRAF6-dependent signal transduction pathway is essential for osteoclast cytoskeletal organization and resorptive function. J. Biol. Chem. 2002, 277, 44347-44356. [CrossRef] [PubMed]

25. Campbell, J.P.; Karolak, M.R.; Ma, Y.; Perrien, D.S.; Masood-Campbell, S.K.; Penner, N.L.; Munoz, S.A.; Zijlstra, A.; Yang, X.; Sterling, J.A.; et al. Stimulation of host bone marrow stromal cells by sympathetic nerves promotes breast cancer bone metastasis in mice. PLoS Biol. 2012, 10, e1001363. [CrossRef] [PubMed]

26. Wan, X.; Song, Y.; Fang, H.; Xu, L.; Che, X.; Wang, S.; Zhang, X.; Zhang, L.; Li, C.; Fan, Y.; et al. RANKL/RANK promotes the migration of gastric cancer cells by interacting with EGFR. Clin. Transl. Med. 2020, 9, 3. [CrossRef]

27. Simonet, W.S.; Lacey, D.L.; Dunstan, C.R.; Kelley, M.; Chang, M.-S.; Lüthy, R.; Nguyen, H.Q.; Wooden, S.; Bennett, L.; Boone, T.; et al. Osteoprotegerin: A novel secreted protein involved in the regulation of bone density. Cell 1997, 89, 309-319. [CrossRef]

28. Ono, T.; Nakashima, T. Recent advances in osteoclast biology. Histochem. Cell Biol. 2018, 149, 325-341. [CrossRef]

29. Maurizi, A.; Rucci, N. The Osteoclast in Bone Metastasis: Player and Target. Cancers 2018, 10, 218. [CrossRef] [PubMed]

30. Eriksen, E.F. Cellular mechanisms of bone remodeling. Rev. Endocr. Metab. Disord. 2010, 11, 219-227. [CrossRef] [PubMed]

31. Boskey, A.L.; Coleman, R. Aging and Bone. J. Dent. Res. 2010, 89, 1333-1348. [CrossRef] [PubMed]

32. Demontiero, O.; Vidal, C.; Duque, G. Aging and bone loss: New insights for the clinician. Ther. Adv. Musculoskelet. Dis. 2011, 4, 61-76. [CrossRef]

33. Bussard, K.M.; Gay, C.V.; Mastro, A.M. The bone microenvironment in metastasis; what is special about bone? Cancer Metastasis Rev. 2008, 27, 41-55. [CrossRef]

34. Kusumbe, A.P. Vascular niches for disseminated tumour cells in bone. J. Bone Oncol. 2016, 5, 112-116. [CrossRef] [PubMed]

35. Sosa, M.S.; Bragado, P.; Aguirre-Ghiso, J.A. Mechanisms of disseminated cancer cell dormancy: An awakening field. Nat. Rev. Cancer 2014, 14, 611-622. [CrossRef]

36. Huang, J.-F.; Shen, J.; Li, X.; Rengan, R.; Silvestris, N.; Wang, M.; DeRosa, L.; Zheng, X.; Belli, A.; Zhang, X.-L.; et al. Incidence of patients with bone metastases at diagnosis of solid tumors in adults: A large population-based study. Ann. Transl. Med. 2020, 8, 482. [CrossRef] [PubMed]

37. D'Amico, L.; Satolli, M.A.; Mecca, C.; Castiglione, A.; Ceccarelli, M.; D'Amelio, P.; Garino, M.; De Giuli, M.; Sandrucci, S.; Ferracini, R.; et al. Bone metastases in gastric cancer follow a RANKL-independent mechanism. Oncol. Rep. 2013, 29, 1453-1458. [CrossRef] [PubMed]

38. Hsieh, H.-L.; Tsai, M.-M. Tumor progression-dependent angiogenesis in gastric cancer and its potential application. World J. Gastrointest. Oncol. 2019, 11, 686-704. [CrossRef]

39. Ammendola, M.; Marech, I.; Sammarco, G.; Zuccalà, V.; Luposella, M.; Zizzo, N.; Patruno, R.; Crovace, A.; Ruggieri, E.; Zito, A.F.; et al. Infiltrating mast cells correlate with angiogenesis in bone metastases from gastric cancer patients. Int. J. Mol. Sci. 2015, 16, 3237-3250. [CrossRef]

40. Richard, V.; Rosol, T.J.; Foley, J. PTHrP gene expression in cancer: Do all paths lead to Ets? Crit. Rev. Eukaryot. Gene Expr. 2005, 15, 115-132. [CrossRef]

41. Alipov, G.K.; Ito, M.; Nakashima, M.; Ikeda, Y.; Nakayama, T.; Ohtsuru, A.; Yamashita, S.; Sekine, I. Expression of parathyroid hor-mone-related peptide (PTHrP) in gastric tumours. J. Pathol. 1997, 182, 174-179. [CrossRef]

42. Ito, M.; Nakashima, M.; Alipov, G.K.; Matsuzaki, S.; Ohtsuru, A.; Yano, H.; Yamashita, S.; Sekine, I. Gastric cancer associated with overexpression of parathyroid hormone-related peptide (PTHrP) and PTH/PTHrP receptor in relation to tumor progression. J. Gastroenterol. 1997, 32, 396-400. [CrossRef]

43. Zhang, X.; Song, Y.; Song, N.; Zhang, L.; Wang, Y.; Li, D.; Wang, Z.; Qu, X.; Liu, Y. Rankl expression predicts poor prognosis in gastric cancer patients: Results from a retrospective and single-center analysis. Braz. J. Med. Biol. Res. 2018, 51, e6265. [CrossRef]

44. Katoh, M.; Terada, M. Overexpression of bone morphogenic protein (BMP)-4 mRNA in gastric cancer cell lines of poorly differentiated type. J. Gastroenterol. 1996, 31, 137-139. [CrossRef] [PubMed]

45. Lee, Y.-C.; Cheng, C.-J.; Bilen, M.A.; Lu, J.-F.; Satcher, R.L.; Yu-Lee, L.-Y.; Gallick, G.E.; Maity, S.N.; Lin, S.-H. BMP4 promotes prostate tumor growth in bone through osteogenesis. Cancer Res. 2011, 71, 5194-5203. [CrossRef] [PubMed]

46. Deng, G.; Chen, Y.; Guo, C.; Yin, L.; Han, Y.; Li, Y.; Fu, Y.; Cai, C.; Shen, H.; Zeng, S. BMP4 promotes the metastasis of gastric cancer by inducing epithelial-mesenchymal transition via ID1. J. Cell Sci. 2020, 133, jcs237222. [CrossRef] [PubMed] 
47. Brook, N.; Brook, E.; Dharmarajan, A.; Dass, C.R.; Chan, A. Breast cancer bone metastases: Pathogenesis and therapeutic targets. Int. J. Biochem. Cell Biol. 2018, 96, 63-78. [CrossRef]

48. Rucci, N.; Angelucci, A. Prostate cancer and bone: The elective affinities. BioMed Res. Int. 2014, 2014, 167035. [CrossRef] [PubMed]

49. Riihimäki, M.; Hemminki, A.; Sundquist, K.; Sundquist, J.; Hemminki, K. Metastatic spread in patients with gastric cancer. Oncotarget 2016, 7, 52307-52316. [CrossRef] [PubMed]

50. Gomi, D.; Fukushima, T.; Kobayashi, T.; Sekiguchi, N.; Sakamoto, A.; Mamiya, K.; Koizumi, T. Gastric cancer initially presenting as bone metastasis: Two case reports and a literature review. Oncol. Lett. 2018, 16, 5863-5867. [CrossRef]

51. Guadagni, S.; Catarci, M.; Kinoshitá, T.; Valenti, M.; De Bernardinis, G.; Carboni, M. Causes of death and recurrence after surgery for early gastric cancer. World J. Surg. 1997, 21, 434-439. [CrossRef]

52. Turkoz, F.P.; Solak, M.; Kilickap, S.; Ulas, A.; Esbah, O.; Oksuzoglu, B.; Yalcin, S. Bone metastasis from gastric cancer: The incidence, clinicopathological features, and influence on survival. J. Gastric Cancer 2014, 14, 164-172. [CrossRef]

53. Ahn, J.B.; Ha, T.K.; Kwon, S.J. Bone metastasis in gastric cancer patients. J. Gastric Cancer 2011, 11, 38-45. [CrossRef]

54. Clézardin, P. Pathophysiology of bone metastases from solid malignancies. Jt. Bone Spine 2017, 84, 677-684. [CrossRef]

55. Silvestris, N.; Pantano, F.; Ibrahim, T.; Gamucci, T.; De Vita, F.; Di Palma, T.; Pedrazzoli, P.; Barni, S.; Bernardo, A.; Febbraro, A.; et al. Natural history of malignant bone disease in gastric cancer: Final results of a multicenter bone metastasis survey. PLoS ONE 2013, 8, e74402. [CrossRef]

56. Wen, L.; Li, Y.-Z.; Zhang, J.; Zhou, C.; Yang, H.-N.; Chen, X.-Z.; Xu, L.-W.; Kong, S.-N.; Wang, X.-W.; Zhang, H.-M. Clinical analysis of bone metastasis of gastric cancer: Incidence, clinicopathological features and survival. Future Oncol. 2019, 15, $2241-2249$. [CrossRef]

57. Liang, C.; Chen, H.; Yang, Z.; Han, C.; Ren, C. Risk factors and prognosis of bone metastases in newly diagnosed gastric cancer. Future Oncol. 2020, 16, 733-748. [CrossRef]

58. Qiu, M.-Z.; Shi, S.-M.; Chen, Z.-H.; Yu, H.-E.; Sheng, H.; Jin, Y.; Wang, D.-S.; Wang, F.-H.; Li, Y.-H.; Xie, D.; et al. Frequency and clinicopathological features of metastasis to liver, lung, bone, and brain from gastric cancer: A SEER-based study. Cancer Med. 2018, 7, 3662-3672. [CrossRef]

59. Park, H.S.; Rha, S.Y.; Kim, H.S.; Hyung, W.J.; Park, J.S.; Chung, H.C.; Noh, S.H.; Jeung, H.-C. A prognostic model to predict clinical outcome in gastric cancer patients with bone metastasis. Oncology 2011, 80, 142-150. [CrossRef] [PubMed]

60. Nakamura, K.; Tomioku, M.; Nabeshima, K.; Yasuda, S. Clinicopathologic features and clinical outcomes of gastric cancer patients with bone metastasis. Tokai J. Exp. Clin. Med. 2014, 39, 193-198. [PubMed]

61. Mikami, J.; Kimura, Y.; Makari, Y.; Fujita, J.; Kishimoto, T.; Sawada, G.; Nakahira, S.; Nakata, K.; Tsujie, M.; Ohzato, H. Clinical outcomes and prognostic factors for gastric cancer patients with bone metastasis. World J. Surg. Oncol. 2017, 15, 8. [CrossRef] [PubMed]

62. Imura, Y.; Tateiwa, D.; Sugimoto, N.; Inoue, A.; Wakamatsu, T.; Outani, H.; Tanaka, T.; Tamiya, H.; Yagi, T.; Naka, N.; et al. Prognostic factors and skeletal-related events in patients with bone metastasis from gastric cancer. Mol. Clin. Oncol. 2020, 13, 31. [CrossRef]

63. Laurén, P. The two histological main types of gastric carcinoma: Diffuse and so-called intestinal-type carcinoma. An attempt at a histo-clinical classification. Acta Pathol. Microbiol. Scand. 1965, 64, 31-49. [CrossRef]

64. Miyamoto, W.; Yamamoto, S.; Uchio, Y. Metastasis of gastric cancer to the fifth metacarpal bone. Hand Surg. 2008, 13, 193-195. [CrossRef] [PubMed]

65. Harris, H.; Khan, M.; Jaunoo, S. Distal phalanx: An unusual site for a gastric adenocarcinoma metastasis. BMJ Case Rep. 2020, 13, e236259. [CrossRef] [PubMed]

66. Okamoto, M.; Yamazaki, H.; Yoshimura, Y.; Aoki, K.; Tanaka, A.; Kato, H. Massive trapezial metastasis from gastric adenocarcinoma resected and reconstructed with a vascularized scapular bone graft. A case report. Medicine 2017, 96, e9294. [CrossRef] [PubMed]

67. Chang, H.C.; Lew, K.H.; Low, C.O. Metastasis of an adenocarcinoma of the stomach to the 4th metacarpal bone. Hand Surg. 2001, 6, 239-242. [CrossRef]

68. Kumar, A. Acrometastases to the hand in stomach carcinoma: A rare entity. BMJ Case Rep. 2019, 12, e229390. [CrossRef]

69. Gurzu, S.; Jung, I.; Kádár, Z. Aberrant metastatic behavior and particular features of early gastric cancer. APMIS 2015, 123, 999-1006. [CrossRef]

70. Fujita, I.; Toyokawa, T.; Makino, T.; Matsueda, K.; Omote, S.; Horii, J. Small early gastric cancer with synchronous bone metastasis: A case report. Mol. Clin. Oncol. 2020, 12, 202-207. [CrossRef]

71. Park, J.M.; Song, K.Y.; O, J.H.; Kim, W.C.; Choi, M.-G.; Park, C.H. Bone recurrence after curative resection of gastric cancer. Gastric Cancer 2013, 16, 362-369. [CrossRef]

72. Blanchette, P.; Lipton, J.; Barth, D.; Mackay, H. Case Report of very late gastric cancer recurrence. Curr. Oncol. 2013, 20, 161-164. [CrossRef] [PubMed]

73. Iovino, F.; Orditura, M.; Auriemma, P.P.; Ciorra, F.R.; Giordano, G.; Orabona, C.; Bara, F.; Sergio, R.; Savastano, B.; Fabozzi, A.; et al. Vertebral carcinomatosis eleven years after advanced gastric cancer resection: A case report. Oncol. Lett. 2015, 9, 1403-1405. [CrossRef] 
74. Di Nunno, V.; Mollica, V.; Schiavina, R.; Nobili, E.; Fiorentino, M.; Brunocilla, E.; Ardizzoni, A.; Massari, F. Improving IMDC Prognostic Prediction Through Evaluation of Initial Site of Metastasis in Patients with Metastatic Renal Cell Carcinoma. Clin. Genitourin. Cancer 2020, 18, e83-e90. [CrossRef]

75. Massari, F.; Di Nunno, V.; Guida, A.; Silva, C.A.C.; Derosa, L.; Mollica, V.; Colomba, E.; Brandi, G.; Albiges, L. Addition of Primary Metastatic Site on Bone, Brain, and Liver to IMDC Criteria in Patients with Metastatic Renal Cell Carcinoma: A Validation Study. Clin. Genitourin. Cancer 2021, 19, 32-40. [CrossRef] [PubMed]

76. National Comprehensive Cancer Network (NCCN). Clinical Practice Guidelines in Oncology. Gastric Cancer, Version 1. 2020. Available online: https://www.nccn.org/guidelines/guidelines-detail?category=1\&id=1434 (accessed on 15 November 2020).

77. Nilsson, M. Postgastrectomy follow-up in the West: Evidence base, guidelines, and daily practice. Gastric Cancer 2017, 20 (Suppl. S1), 135-140. [CrossRef]

78. Lim, S.M.; Kim, Y.N.; Park, K.H.; Kang, B.; Chon, H.J.; Kim, C.; Kim, J.H.; Rha, S.Y. Bone alkaline phosphatase as a surrogate marker of bone metastasis in gastric cancer patients. BMC Cancer 2016, 16, 385. [CrossRef] [PubMed]

79. Kawamura, T.; Kusakabe, T.; Sugino, T.; Watanabe, K.; Fukuda, T.; Nashimoto, A.; Honma, K.; Suzuki, T. Expression of glucose transporter-1 in human gastric carcinoma: Association with tumor aggressiveness, metastasis, and patient survival. Cancer 2001, 92, 634-641. [CrossRef]

80. Grillo, A.; Capasso, R.; Petrillo, A.; De Vita, F.; Conforti, R. An intramedullary "flame" recognized as being an intramedullary spinal cord metastasis from esophageal cancer. J. Radiol. Case Rep. 2019, 13, 14-20. [CrossRef]

81. Eisenhauer, E.A.; Therasse, P.; Bogaerts, J.; Schwartz, L.H.; Sargent, D.; Ford, R.; Dancey, J.; Arbuck, S.; Gwyther, S.; Mooney, M.; et al. New response evaluation criteria in solid tumours: Revised RECIST guideline (version 1.1). Eur. J. Cancer 2009, 45, $228-247$. [CrossRef]

82. Pollen, J.J.; Witztum, K.F.; Ashburn, W.L. The flare phenomenon on radionuclide bone scan in metastatic prostate cancer. Am. J. Roentgenol. 1984, 142, 773-776. [CrossRef]

83. Fogelman, I. The flare phenomenon: Still learning after 35 years. Eur. J. Nucl. Med. Mol. Imaging 2011, 38, 5-6. [CrossRef]

84. Cook, G.J.; Venkitaraman, R.; Sohaib, A.S.; Lewington, V.J.; Chua, S.C.; Huddart, R.A.; Parker, C.C.; Dearnaley, D.D.; Horwich, A. The diagnostic utility of the flare phenomenon on bone scintigraphy in staging prostate cancer. Eur. J. Nucl. Med. Mol. Imaging 2011, 38, 7-13. [CrossRef]

85. De Bondt, C.; Snoeckx, A.; Raskin, J. A Flare for the Unexpected: Bone Flare as Response to Tyrosine Kinase Inhibitor Treatment in a Lung Cancer Patient: New osteoblastic bone lesions in a lung cancer patient may represent bone flare and should not be misdiagnosed as disease progression. J. Belg. Soc. Radiol. 2020, 104, 18. [CrossRef]

86. Harisankar, C.N.B.; Preethi, R.; John, J. Metabolic flare phenomenon on 18 fluoride-fluorodeoxy glucose positron emission tomography-computed tomography scans in a patient with bilateral breast cancer treated with second-line chemotherapy and bevacizumab. Indian J. Nucl. Med. 2015, 30, 145-147. [CrossRef]

87. Hashisako, M.; Wakamatsu, K.; Ikegame, S.; Kumazoe, H.; Nagata, N.; Kajiki, A. Flare phenomenon following gefitinib treatment of lung adenocarcinoma with bone metastasis. Tohoku J. Exp. Med. 2012, 228, 163-168. [CrossRef] [PubMed]

88. Lu, M.-C.; Chuang, T.-L.; Lee, M.-S.; Chiou, W.-Y.; Lin, H.-Y.; Hung, S.-K. The Super-scan and Flare Phenomena in a Nasopharyngeal Cancer Patient: A Case Report. J. Clin. Med. Res. 2012, 4, 221-223. [CrossRef]

89. Amoroso, V.; Pittiani, F.; Grisanti, S.; Valcamonico, F.; Simoncini, E.; Ferrari, V.D.; Marini, G. Osteoblastic flare in a patient with advanced gastric cancer after treatment with pemetrexed and oxaliplatin: Implications for response assessment with RECIST criteria. BMC Cancer 2007, 7, 94. [CrossRef] [PubMed]

90. Lee, S.; Shi, H.; Sohn, S.; Park, S.; Wang, S.; Song, J.; Jang, G. The Flare Phenomenon in a Patient with Advanced Gastric Cancer with Bone Metastases. Korean J. Med. 2016, 91, 321-324. [CrossRef]

91. Al-Batran, S.-E.; Hartmann, J.T.; Probst, S.; Schmalenberg, H.; Hollerbach, S.; Hofheinz, R.; Rethwisch, V.; Seipelt, G.; Homann, N.; Wilhelm, G.; et al. Phase III trial in metastatic gastroesophageal adenocarcinoma with fluorouracil, leucovorin plus either oxaliplatin or cisplatin: A study of the arbeitsgemeinschaft internistische onkologie. J. Clin. Oncol. 2008, 26, 1435-1442. [CrossRef]

92. Kang, Y.; Kang, W.K.; Shin, D.B.; Chen, J.; Xiong, J.; Wang, J.; Lichinitser, M.; Philco, M.; Suarez, T.; Santamaria, J. Randomized phase III trial of capecitabine/cisplatin (XP) vs. continuous infusion of 5-FU/cisplatin (FP) as first-line therapy in patients (pts) with advanced gastric cancer (AGC): Efficacy and safety results. J. Clin. Oncol. 2006, 24 (Suppl. S18), LBA4018. [CrossRef]

93. Ryu, M.-H.; Baba, E.; Lee, K.H.; Park, Y.I.; Boku, N.; Hyodo, I.; Nam, B.-H.; Esaki, T.; Yoo, C.; Ryoo, B.-Y.; et al. Comparison of two different S-1 plus cisplatin dosing schedules as first-line chemotherapy for metastatic and/or recurrent gastric cancer: A multicenter, randomized phase III trial (SOS). Ann. Oncol. 2015, 26, 2097-2101. [CrossRef] [PubMed]

94. Kang, J.H.; Lee, S.I.; Lim, D.H.; Park, K.-W.; Oh, S.Y.; Kwon, H.-C.; Hwang, I.G.; Lee, S.-C.; Nam, E.; Shin, D.B.; et al. Salvage chemotherapy for pretreated gastric cancer: A randomized phase III trial comparing chemotherapy plus best supportive care with best supportive care alone. J. Clin. Oncol. 2012, 30, 1513-1518. [CrossRef]

95. Shen, L.; Li, J.; Xu, J.; Pan, H.; Dai, G.; Qin, S.; Wang, L.; Wang, J.; Yang, Z.; Shu, Y.; et al. Bevacizumab plus capecitabine and cisplatin in Chinese patients with inoperable locally advanced or metastatic gastric or gastroesophageal junction cancer: Randomized, double-blind, phase III study (AVATAR study). Gastric Cancer 2015, 18, 168-176. [CrossRef] [PubMed]

96. Pavlakis, N.; Sjoquist, K.M.; Martin, A.J.; Tsobanis, E.; Yip, S.; Kang, Y.-K.; Bang, Y.-J.; Alcindor, T.; O'Callaghan, C.J.; Burnell, M.J.; et al. Regorafenib for the Treatment of Advanced Gastric Cancer (INTEGRATE): A Multinational Placebo-Controlled Phase II Trial. J. Clin. Oncol. 2016, 34, 2728-2735. [CrossRef] [PubMed] 
97. Kang, Y.-K.; Boku, N.; Satoh, T.; Ryu, M.-H.; Chao, Y.; Kato, K.; Chung, H.C.; Chen, J.-S.; Muro, K.; Kang, W.K.; et al. Nivolumab in patients with advanced gastric or gastro-oesophageal junction cancer refractory to, or intolerant of, at least two previous chemotherapy regimens (ONO-4538-12, ATTRACTION-2): A randomised, double-blind, placebo-controlled, phase 3 trial. Lancet 2017, 390, 2461-2471. [CrossRef]

98. Chen, L.-T.; Satoh, T.; Ryu, M.-H.; Chao, Y.; Kato, K.; Chung, H.C.; Chen, J.-S.; Muro, K.; Kang, W.K.; Yeh, K.-H.; et al. A phase 3 study of nivolumab in previously treated advanced gastric or gastroesophageal junction cancer (ATTRACTION-2): 2-year update data. Gastric Cancer 2020, 23, 510-519. [CrossRef]

99. Van Cutsem, E.; Moiseyenko, V.M.; Tjulandin, S.; Majlis, A.; Constenla, M.; Boni, C.; Rodrigues, A.; Fodor, M.; Chao, Y.; Voznyi, E.; et al. V325 Study Group. Phase III study of docetaxel and cisplatin plus fluorouracil compared with cisplatin and fluorouracil as first-line therapy for advanced gastric cancer: A report of the V325 Study Group. J. Clin. Oncol. 2006, 24, 4991-4997. [CrossRef]

100. Dank, M.; Zaluski, J.; Barone, C.; Valvere, V.; Yalcin, S.; Peschel, C.; Wenczl, M.; Goker, E.; Cisar, L.; Wang, K.; et al. Randomized phase III study comparing irinotecan combined with 5-fluorouracil and folinic acid to cisplatin combined with 5-fluorouracil in chemotherapy naive patients with advanced adenocarcinoma of the stomach or esophagogastric junction. Ann. Oncol. 2008, 19, 1450-1457. [CrossRef] [PubMed]

101. Cunningham, D.; Starling, N.; Rao, S.; Iveson, T.; Nicolson, M.; Coxon, F.; Middleton, G.; Daniel, F.; Oates, J.; Norman, A.R. Capecitabine and Oxaliplatin for Advanced Esophagogastric Cancer. New Engl. J. Med. 2008, 358, 36-46. [CrossRef]

102. Ajani, J.A.; Rodriguez, W.; Bodoky, G.; Moiseyenko, V.; Lichinitser, M.; Gorbunova, V.; Vynnychenko, I.; Garin, A.; Lang, I.; Falcon, S. Multicenter Phase III Comparison of Cisplatin/S-1 With Cisplatin/Infusional Fluorouracil in Advanced Gastric or Gastroesophageal Adenocarcinoma Study: The FLAGS Trial. J. Clin. Oncol. 2010, 28, 1547-1553. [CrossRef]

103. NaraharaHiroyasu, H.; Iishi, H.; Imamura, H.; Tsuburaya, A.; Chin, K.; Imamoto, H.; Esaki, T.; Furukawa, H.; Hamada, C.; Sakata, Y. Randomized phase III study comparing the efficacy and safety of irinotecan plus S-1 with S-1 alone as first-line treatment for advanced gastric cancer (study GC0301/TOP-002). Gastric Cancer 2011, 14, 72-80. [CrossRef]

104. Guimbaud, R.; Louvet, C.; Ries, P.; Ychou, M.; Maillard, E.; André, T.; Gornet, J.-M.; Aparicio, T.; Nguyen, S.; Azzedine, A.; et al. Prospective, Randomized, Multicenter, Phase III Study of Fluorouracil, Leucovorin, and Irinotecan Versus Epirubicin, Cisplatin, and Capecitabine in Advanced Gastric Adenocarcinoma: A French Intergroup (Fédération Francophone de Cancérologie Digestive, Fédération Nationale des Centres de Lutte Contre le Cancer, and Groupe Coopérateur Multidisciplinaire en Oncologie) Study. J. Clin. Oncol. 2014, 32, 3520-3526. [CrossRef] [PubMed]

105. Yamada, Y.; Higuchi, K.; Nishikawa, K.; Gotoh, M.; Fuse, N.; Sugimoto, N.; Nishina, T.; Amagai, K.; Chin, K.; Niwa, Y.; et al. Phase III study comparing oxaliplatin plus S-1 with cisplatin plus S-1 in chemotherapy-naïve patients with advanced gastric cancer. Ann. Oncol. 2015, 26, 141-148. [CrossRef] [PubMed]

106. Thuss-Patience, P.C.; Kretzschmar, A.; Bichev, D.; Deist, T.; Hinke, A.; Breithaupt, K.; Dogan, Y.; Gebauer, B.; Schumacher, G.; Reichardt, P. Survival advantage for irinotecan versus best supportive care as second-line chemotherapy in gastric cancer-A randomised phase III study of the Arbeitsgemeinschaft Internistische Onkologie (AIO). Eur. J. Cancer 2011, 47, $2306-2314$. [CrossRef] [PubMed]

107. Hironaka, S.; Ueda, S.; Yasui, H.; Nishina, T.; Tsuda, M.; Tsumura, T.; Sugimoto, N.; Shimodaira, H.; Tokunaga, S.; Moriwaki, T.; et al. Randomized, Open-Label, Phase III Study Comparing Irinotecan With Paclitaxel in Patients With Advanced Gastric Cancer Without Severe Peritoneal Metastasis After Failure of Prior Combination Chemotherapy Using Fluoropyrimidine Plus Platinum: WJOG 4007 Trial. J. Clin. Oncol. 2013, 31, 4438-4444. [CrossRef] [PubMed]

108. Ford, H.E.R.; Marshall, A.; A Bridgewater, J.; Janowitz, T.; Coxon, F.Y.; Wadsley, J.; Mansoor, W.; Fyfe, D.; Madhusudan, S.; Middleton, G.W.; et al. Docetaxel versus active symptom control for refractory oesophagogastric adenocarcinoma (COUGAR-02): An open-label, phase 3 randomised controlled trial. Lancet Oncol. 2014, 15, 78-86. [CrossRef]

109. Shitara, K.; Takashima, A.; Fujitani, K.; Koeda, K.; Hara, H.; Nakayama, N.; Hironaka, S.; Nishikawa, K.; Makari, Y.; Amagai, K.; et al. Nab-paclitaxel versus solvent-based paclitaxel in patients with previously treated advanced gastric cancer (ABSOLUTE): An open-label, randomised, non-inferiority, phase 3 trial. Lancet Gastroenterol. Hepatol. 2017, 2, 277-287. [CrossRef]

110. Shitara, K.; Doi, T.; Dvorkin, M.; Mansoor, W.; Arkenau, H.-T.; Prokharau, A.; Alsina, M.; Ghidini, M.; Faustino, C.; Gorbunova, V.; et al. Trifluridine/tipiracil versus placebo in patients with heavily pretreated metastatic gastric cancer (TAGS): A randomised, double-blind, placebo-controlled, phase 3 trial. Lancet Oncol. 2018, 19, 1437-1448. [CrossRef]

111. Ohtsu, A.; Shah, M.A.; Van Cutsem, E.; Rha, S.Y.; Sawaki, A.; Park, S.R.; Lim, H.Y.; Yamada, Y.; Wu, J.; Langer, B.; et al. Bevacizumab in Combination With Chemotherapy As First-Line Therapy in Advanced Gastric Cancer: A Randomized, DoubleBlind, Placebo-Controlled Phase III Study. J. Clin. Oncol. 2011, 29, 3968-3976. [CrossRef]

112. Bang, Y.-J.; Van Cutsem, E.; Feyereislova, A.; Chung, H.C.; Shen, L.; Sawaki, A.; Lordick, F.; Ohtsu, A.; Omuro, Y.; Satoh, T.; et al. Trastuzumab in combination with chemotherapy versus chemotherapy alone for treatment of HER2-positive advanced gastric or gastro-oesophageal junction cancer (ToGA): A phase 3, open-label, randomised controlled trial. Lancet 2010, 376, 687-697. [CrossRef]

113. Lordick, F.; Kang, Y.-K.; Chung, H.-C.; Salman, P.; Oh, S.C.; Bodoky, G.; Kurteva, G.; Volovat, C.; Moiseyenko, V.M.; Gorbunova, V.; et al. Capecitabine and cisplatin with or without cetuximab for patients with previously untreated advanced gastric cancer (EXPAND): A randomised, open-label phase 3 trial. Lancet Oncol. 2013, 14, 490-499. [CrossRef] 
114. Waddell, T.; Chau, I.; Cunningham, D.; Gonzalez, D.; Okines, A.F.C.; Wotherspoon, A.; Saffery, C.; Middleton, G.; Wadsley, J.; Ferry, D.; et al. Epirubicin, oxaliplatin, and capecitabine with or without panitumumab for patients with previously untreated advanced oesophagogastric cancer (REAL3): A randomised, open-label phase 3 trial. Lancet Oncol. 2013, 14, 481-489. [CrossRef]

115. Al-Batran, S.-E.; Schuler, M.H.; Zvirbule, Z.; Manikhas, G.; Lordick, F.; Rusyn, A.; Vynnyk, Y.; Vynnychenko, I.; Fadeeva, N.; Nechaeva, M.; et al. FAST: An international, multicenter, randomized, phase II trial of epirubicin, oxaliplatin, and capecitabine (EOX) with or without IMAB362, a first-in-class anti-CLDN18.2 antibody, as first-line therapy in patients with advanced CLDN18.2+ gastric and gastroesophageal junction (GEJ) adenocarcinoma. J. Clin. Oncol. 2016, 34, LBA4001. [CrossRef]

116. Hecht, J.R.; Bang, Y.-J.; Qin, S.K.; Chung, H.C.; Xu, J.M.; Park, J.O.; Jeziorski, K.; Shparyk, Y.; Hoff, P.M.; Sobrero, A.; et al. Lapatinib in Combination With Capecitabine Plus Oxaliplatin in Human Epidermal Growth Factor Receptor 2-Positive Advanced or Metastatic Gastric, Esophageal, or Gastroesophageal Adenocarcinoma: TRIO-013/LOGiC—A Randomized Phase III Trial. J. Clin. Oncol. 2016, 34, 443-451. [CrossRef]

117. Shah, M.A.; Bang, Y.-J.; Lordick, F.; Alsina, M.; Chen, M.; Hack, S.P.; Bruey, J.M.; Smith, D.; McCaffery, I.; Shames, D.S.; et al. Effect of Fluorouracil, Leucovorin, and Oxaliplatin With or Without Onartuzumab in HER2-Negative, MET-Positive Gastroesophageal Adenocarcinoma. JAMA Oncol. 2017, 3, 620-627. [CrossRef]

118. Cunningham, D.; Al-Batran, S.-E.; Davidenko, I.; Ilson, D.H.; Murad, A.M.; Tebbutt, N.C.; Jiang, Y.; Loh, E.; Dubey, S. RILOMET1 investigators RILOMET-1: An international phase III multicenter, randomized, double-blind, placebo-controlled trial of rilotumumab plus epirubicin, cisplatin, and capecitabine (ECX) as first-line therapy in patients with advanced MET-positive gastric or gastroesophageal junction (G/GEJ) adenocarcinoma. J. Clin. Oncol. 2013, 31, TPS4153. [CrossRef]

119. Shah, M.A.; Xu, R.-H.; Bang, Y.-J.; Hoff, P.M.; Liu, T.; Herráez-Baranda, L.A.; Xia, F.; Garg, A.; Shing, M.; Tabernero, J. HELOISE: Phase IIIb Randomized Multicenter Study Comparing Standard-of-Care and Higher-Dose Trastuzumab Regimens Combined With Chemotherapy as First-Line Therapy in Patients With Human Epidermal Growth Factor Receptor 2-Positive Metastatic Gastric or Gastroesophageal Junction Adenocarcinoma. J. Clin. Oncol. 2017, 35, 2558-2567. [CrossRef]

120. Tabernero, J.; Hoff, P.M.; Shen, L.; Ohtsu, A.; A Shah, M.; Cheng, K.; Song, C.; Wu, H.; Eng-Wong, J.; Kim, K.; et al. Pertuzumab plus trastuzumab and chemotherapy for HER2-positive metastatic gastric or gastro-oesophageal junction cancer (JACOB): Final analysis of a double-blind, randomised, placebo-controlled phase 3 study. Lancet Oncol. 2018, 19, 1372-1384. [CrossRef]

121. Fuchs, C.S.; Shitara, K.; Di Bartolomeo, M.; Lonardi, S.; Al-Batran, S.-E.; Van Cutsem, E.; Ilson, D.H.; Alsina, M.; Chau, I.; Lacy, J.; et al. Ramucirumab with cisplatin and fluoropyrimidine as first-line therapy in patients with metastatic gastric or junctional adenocarcinoma (RAINFALL): A double-blind, randomised, placebo-controlled, phase 3 trial. Lancet Oncol. 2019, 20, 420-435. [CrossRef]

122. Ohtsu, A.; Ajani, J.A.; Bai, Y.-X.; Bang, Y.-J.; Chung, H.-C.; Pan, H.-M.; Sahmoud, T.; Shen, L.; Yeh, K.-H.; Chin, K.; et al. Everolimus for Previously Treated Advanced Gastric Cancer: Results of the Randomized, Double-Blind, Phase III GRANITE-1 Study. J. Clin. Oncol. 2013, 31, 3935-3943. [CrossRef]

123. Fuchs, C.S.; Tomasek, J.; Yong, C.J.; Dumitru, F.; Passalacqua, R.; Goswami, C.; Safran, H.; dos Santos, L.V.; Aprile, G.; Ferry, D.R.; et al. Ramucirumab monotherapy for previously treated advanced gastric or gastro-oesophageal junction adenocarcinoma (REGARD): An international, randomised, multicentre, placebo-controlled, phase 3 trial. Lancet 2014, 383, 31-39. [CrossRef]

124. Wilke, H.; Muro, K.; Van Cutsem, E.; Oh, S.-C.; Bodoky, G.; Shimada, Y.; Hironaka, S.; Sugimoto, N.; Lipatov, O.; Kim, T.-Y.; et al. Ramucirumab plus paclitaxel versus placebo plus paclitaxel in patients with previously treated advanced gastric or gastro-oesophageal junction adenocarcinoma (RAINBOW): A double-blind, randomised phase 3 trial. Lancet Oncol. 2014, 15, 1224-1235. [CrossRef]

125. Satoh, T.; Xu, R.-H.; Chung, H.C.; Sun, G.-P.; Doi, T.; Xu, J.-M.; Tsuji, A.; Omuro, Y.; Li, J.; Wang, J.-W.; et al. Lapatinib Plus Paclitaxel Versus Paclitaxel Alone in the Second-Line Treatment ofHER2-Amplified Advanced Gastric Cancer in Asian Populations: TyTAN-A Randomized, Phase III Study. J. Clin. Oncol. 2014, 32, 2039-2049. [CrossRef]

126. Van Cutsem, E.; Bang, Y.-J.; Mansoor, W.; Petty, R.D.; Chao, Y.; Cunningham, D.; Ferry, D.R.; Smith, N.R.; Frewer, P.; Ratnayake, J.; et al. A randomized, open-label study of the efficacy and safety of AZD4547 monotherapy versus paclitaxel for the treatment of advanced gastric adenocarcinoma with FGFR2 polysomy or gene amplification. Ann. Oncol. 2017, 28, 1316-1324. [CrossRef] [PubMed]

127. Thuss-Patience, P.C.; A Shah, M.; Ohtsu, A.; Van Cutsem, E.; Ajani, J.A.; Castro, H.; Mansoor, W.; Chung, H.C.; Bodoky, G.; Shitara, K.; et al. Trastuzumab emtansine versus taxane use for previously treated HER2-positive locally advanced or metastatic gastric or gastro-oesophageal junction adenocarcinoma (GATSBY): An international randomised, open-label, adaptive, phase 2/3 study. Lancet Oncol. 2017, 18, 640-653. [CrossRef]

128. Bang, Y.-J.; Xu, R.-H.; Chin, K.; Lee, K.-W.; Park, S.H.; Rha, S.Y.; Shen, L.; Qin, S.; Xu, N.; Im, S.-A.; et al. Olaparib in combination with paclitaxel in patients with advanced gastric cancer who have progressed following first-line therapy (GOLD): A double-blind, randomised, placebo-controlled, phase 3 trial. Lancet Oncol. 2017, 18, 1637-1651. [CrossRef]

129. Kang, Y.-K.; Kang, W.; Di Bartolomeo, M.; Chau, I.; Yoon, H.; Cascinu, S.; Ryu, M.-H.; Kim, J.; Lee, K.-W.; Oh, S.; et al. Randomized phase III ANGEL study of rivoceranib (apatinib) + best supportive care (BSC) vs placebo + BSC in patients with advanced/metastatic gastric cancer who failed $\geq 2$ prior chemotherapy regimens. Ann. Oncol. 2019, 30, v877-v878. [CrossRef]

130. Shitara, K.; Bang, Y.-J.; Iwasa, S.; Sugimoto, N.; Ryu, M.-H.; Sakai, D.; Chung, H.-C.; Kawakami, H.; Yabusaki, H.; Lee, J.; et al. Trastuzumab Deruxtecan in Previously Treated HER2-Positive Gastric Cancer. New Engl. J. Med. 2020, 382, 2419-2430. [CrossRef] 
131. Janjigian, Y.Y.; Maron, S.B.; Chatila, W.K.; Millang, B.; Chavan, S.S.; Alterman, C.; Chou, J.F.; Segal, M.F.; Simmons, M.Z.; Momtaz, P.; et al. First-line pembrolizumab and trastuzumab in HER2-positive oesophageal, gastric, or gastro-oesophageal junction cancer: An open-label, single-arm, phase 2 trial. Lancet Oncol. 2020, 21, 821-831. [CrossRef]

132. Chen, L.; Kang, Y.; Tanimoto, M.; Boku, N. 43544-ATTRACTION-04 (ONO-4538-37): A Randomized, Multicenter, Phase $2 / 3$ Study of Nivolumab (Nivo) Plus chemotherapy in Patients (Pts) with Previously Untreated Advanced or Recurrent Gastric (G) or Gastroesophageal Junction (GEJ) Cancer. Ann. Oncol. 2017, 28 (Suppl. S5), v209-v268. [CrossRef]

133. Kato, K.; Sun, J.; Shah, M.J.; Enzinger, P.C.; Adenis, A.; Doi, T.; Kojima, T.; Metges, J.; Li, Z.; Kim, S.; et al. LBA8_PRPembrolizumab plus chemotherapy versus chemotherapy as first-line therapy in patients with advanced esophageal cancer: The phase 3 KEYNOTE-590 study. Ann. Oncol. 2020, 31 (Suppl. S4), S1142-S1215. [CrossRef]

134. Moehler, M.; Dvorkin, M.; Boku, N.; Özgüroğlu, M.; Ryu, M.H.; Muntean, A.S.; Lonardi, S.; Nechaeva, M.; Bragagnoli, A.C.; Coşkun, H.S.; et al. Phase III Trial of Avelumab Maintenance After First-Line Induction Chemotherapy Versus Continuation of Chemotherapy in Patients With Gastric Cancers: Results From JAVELIN Gastric 100. J Clin Oncol. 2021, 39, 966-977. [CrossRef]

135. Kawazoe, A.; Fukuoka, S.; Nakamura, Y.; Kuboki, Y.; Wakabayashi, M.; Nomura, S.; Mikamoto, Y.; Shima, H.; Fujishiro, N.; Higuchi, T.; et al. Lenvatinib plus pembrolizumab in patients with advanced gastric cancer in the first-line or second-line setting (EPOC1706): An open-label, single-arm, phase 2 trial. Lancet Oncol. 2020, 21, 1057-1065. [CrossRef]

136. Shitara, K.; Özgüroğlu, M.; Bang, Y.-J.; Di Bartolomeo, M.; Mandalà, M.; Ryu, M.-H.; Fornaro, L.; Olesiński, T.; Caglevic, C.; Chung, H.C.; et al. Pembrolizumab versus paclitaxel for previously treated, advanced gastric or gastro-oesophageal junction cancer (KEYNOTE-061): A randomised, open-label, controlled, phase 3 trial. Lancet 2018, 392, 123-133. [CrossRef]

137. Bang, Y.-J.; Ruiz, E.; Van Cutsem, E.; Lee, K.-W.; Wyrwicz, L.; Schenker, M.; Alsina, M.; Ryu, M.-H.; Chung, H.-C.; Evesque, L.; et al. Phase III, randomised trial of avelumab versus physician's choice of chemotherapy as third-line treatment of patients with advanced gastric or gastro-oesophageal junction cancer: Primary analysis of JAVELIN Gastric 300. Ann. Oncol. 2018, 29, 2052-2060. [CrossRef]

138. Bang, Y.-J.; Kang, Y.-K.; Catenacci, D.V.; Muro, K.; Fuchs, C.S.; Geva, R.; Hara, H.; Golan, T.; Garrido, M.; Jalal, S.I.; et al. Pembrolizumab alone or in combination with chemotherapy as first-line therapy for patients with advanced gastric or gastroesophageal junction adenocarcinoma: Results from the phase II nonrandomized KEYNOTE-059 study. Gastric Cancer 2019, 22, 828-837. [CrossRef]

139. Lipton, A.; Cook, R.; Brown, J.; Body, J.; Smith, M.; Coleman, R. Skeletal-related events and clinical outcomes in patients with bone metastases and normal levels of osteolysis: Exploratory analyses. Clin. Oncol. 2013, 25, 217-226. [CrossRef]

140. National Comprehensive Cancer Network (NCCN). Prostate Cancer Guidelines Version 3. 2020. Available online: https: / / www.nccn.org/guidelines / guidelines-detail? category=1\&id=1459 (accessed on 15 November 2020).

141. Rich, S.E.; Chow, R.; Raman, S.; Zeng, K.L.; Lutz, S.; Lam, H.; Silva, M.F.; Chow, E. Update of the systematic review of palliative radiation therapy fractionation for bone metastases. Radiother. Oncol. 2018, 126, 547-557. [CrossRef] [PubMed]

142. Rosen, L.S.; Gordon, D.; Tchekmedyian, S.; Yanagihara, R.; Hirsh, V.; Krzakowski, M.; Pawlicki, M.; De Souza, P.; Zheng, M.; Urbanowitz, G.; et al. Zoledronic acid versus placebo in the treatment of skeletal metastases in patients with lung cancer and other solid tumors: A phase III, double-blind, randomized trial-The Zoledronic Acid Lung Cancer and Other Solid Tumors Study Group. J. Clin. Oncol. 2003, 21, 3150-3157. [CrossRef] [PubMed]

143. Lipton, A.; Fizazi, K.; Stopeck, A.T.; Henry, D.H.; Brown, J.E.; Yardley, D.A.; Richardson, G.E.; Siena, S.; Maroto, P.; Clemens, M.; et al. Superiority of denosumab to zoledronic acid for prevention of skeletal-related events: A combined analysis of 3 pivotal, randomised, phase 3 trials. Eur. J. Cancer 2012, 48, 3082-3092. [CrossRef] [PubMed]

144. Associazione Italiana Oncologi Medici. Linee Guida AIOM 2018, Disordini Elettrolitici. Available online: https://www.aiom. it/disordini-elettrolitici-raccomandazioni-per-liter-diagnostico-terapeutico-nel-paziente-oncologico (accessed on 3 November 2020).

145. Witteveen, J.E.; Van Thiel, S.; Romijn, J.A.; Hamdy, N.A. Hungry bone syndrome: Still a challenge in the post-operative management of primary hyperparathyroidism: A systematic review of the literature. Eur. J. Endocrinol. 2013, 168, R45-R53. [CrossRef] [PubMed]

146. Sakai, K.; Tomoda, Y.; Saito, H.; Tanaka, K. Hungry Bone Syndrome and Osteoblastic Bone Metastasis from Gastric Cancer. QJM: Int. J. Med. 2020, 113, 903-904. [CrossRef] [PubMed]

147. Di Nunno, V.; Cimadamore, A.; Santoni, M.; Scarpelli, M.; Fiorentino, M.; Ciccarese, C.; Iacovelli, R.; Cheng, L.; Lopez-Beltran, A.; Massari, F.; et al. Biological issues with cabozantinib in bone metastatic renal cell carcinoma and castration-resistant prostate cancer. Future Oncol. 2018, 14, 2559-2564. [CrossRef] [PubMed] 